\title{
Microstructure and geochemistry of magmatic dykes from the Arabian margin, Red Sea
}

Davide Zanoni ${ }^{1}$, Najeeb M.A. Rasul ${ }^{2}$, Antonio Langone ${ }^{3}$, and Moustafa Khorshid ${ }^{2}$

1: Università degli Studi di Milano

Dipartimento di Scienze della Terra “A. Desio”

Via Mangiagalli 34

20133 Milano

Italy

2: Saudi Geological Survey

Jeddah

Saudi Arabia

3: CNR-IGG U.O.S. Pavia

Via Ferrata 1

27100 Pavia

Italy

\begin{abstract}
The Red Sea rifting nucleated within the Neoproterozoic Arabian-Nubian shield, which formed during the Pan-African orogeny over a time period of about 300 million years. The Red Sea rifting started about at $30 \mathrm{Ma}$ and was assisted by much diffused magmatism that lasted until recent times. The majority of magmatic rocks consist of basalts that constitute volcanic plateaux (harrats), which represent one of the largest Cenozoic volcanic provinces in the world. Volcanic rocks are distributed all along the Arabian plate margin of the Red Sea, from Yemen to Jordan. Some of the oldest magmatic rocks are acidic in composition, especially along the southern part of the Arabian margin. In this chapter microstructure and geochemistry of acidic, intermediate, and basic dykes sampled along the Arabian margin are described. Acidic dykes consist of granitoids and porphyritic rhyolites. Intermediate and basic dykes consist of andesite and basanite/basalt, respectively. Granitoid dykes show equal-
\end{abstract}


granular coarse-grained texture and mostly consist of euhedral crystals. Other than local displays of crystal-plastic deformation in quartz, these dykes have primary magmatic textures. Dykes consisting of rhyolites contain euhedral K-feldspar phenocrysts with frequent perthitic intergrowth of albite. The rock matrix consists of quartz, K-feldspar, and albite. Basanite/basaltic dykes consist of plagioclase, pyroxene, and amphibole phenocrysts. Plagioclase is also abundant in the groundmass where glass is also preserved. Andesite dykes are characterised by a pervasive alteration that in some instances prevents the identification of original phenocrysts. Where identifiable, phenocrysts consist of plagioclase, amphibole, and pyroxene. Locally, in the groundmass interstitial quartz shows crystal-plastic deformation. Fluidal magmatic structures are recorded locally in basanitic and basaltic dykes and only weakly in rhyolitic dykes. The fine-grained texture of the rock groundmass and vesicular structures indicate that dyke emplacement is quite shallow (hypabyssal conditions). However, the Al-content in amphibole phenocrysts of basanite/basalt dykes is consistent with phenocrysts crystallisation depths of 15 - $20 \mathrm{~km}$. The first U-Pb tests on granitoids reveal that they contain zircon grains from Cryogenian to Ediacaran (middle to late Neoproterozoic) age. Geochemical results indicate that basanite/basaltic dykes are compatible with a divergent environment such as the Red Sea rifting, whereas andesite dykes are compatible with a convergent setting. The rhyolitic dykes are interpreted as related to the Red Sea rifting as they show geochemical signature compatible with divergent tectonics and are from a region where rhyolitic dykes were dated around $20 \mathrm{Ma}$.

\section{Introduction}

Microstructural analysis is a fundamental tool that contributes to the investigation of rock forming processes, deformation, and transformation, giving the rock history throughout different petrogenetic environments. Such a rock history is reconstructed by analysing relict microstructural sites saved because of the heterogeneous partitioning of deformation and mineral transformation, which commonly affects crystalline rocks, and individuating overprinting relationships of micro-structures and mineral assemblages (e.g. Gosso et al. 2015 and references therein). This chapter discusses microstructures and geochemistry of five acidic, three intermediate, and two basic dykes occurring along the Arabian side of the Red Sea (Fig. 1), between the Al Lith and Tabuk regions that are located on the Red Sea coast approximately $150 \mathrm{~km}$ south of Jeddah, and $100 \mathrm{~km}$ south of the Jordan-Saudi Arabian border about $100 \mathrm{~km}$ east of the Red Sea coast, respectively. Acidic dykes consist of 
granitoid and rhyolite, intermediate dykes consist of andesite, and basic dykes consist of basalt and basanite. This chapter aims providing information on the mineral and bulk rock chemical composition, microstructures, and alteration state recorded by the dykes. Also, we report the first test results on zircon $\mathrm{U}-\mathrm{Pb}$ geochronology of three acidic dykes. On the basis of these data, the tectonic setting of dyke emplacement is inferred, along with estimations of the depth and temperature of dyke emplacement.

\section{Geological setting of the Red Sea}

The western and southern margins of the Arabian plate are bounded by two rift basins, namely the Red Sea and Gulf of Aden, which nucleated within Precambrian rocks of the PanAfrican Nubian-Arabian shield. These two rift basins are connected to the Afar zone where a large mantle plume is documented (Rooney et al. 2012). In particular, the rifting propagated southward and westward in the southern Red Sea and Gulf of Aden, respectively (Cochran 1981; Courtillot et al. 1987; Audin et al. 2004; Schettino et al. 2016). However, continental rifting and oceanisation are older in the Gulf of Aden than in the Red Sea. In the Gulf of Aden rifting started at $35 \mathrm{Ma}$ and predated the formation of the first oceanic spreading that occurred at 20 Ma in the eastern part (Roger et al. 1989; Fournier et al. 2010).

Lying between Africa and Arabia, the Red Sea is a narrow basin (about $2000 \mathrm{~km}$ long and up to $355 \mathrm{~km}$ wide) floored by oceanic, transitional, or thinned continental crust. According to most workers, the Red Sea rifting started in the late Oligocene and it is still ongoing north of $24^{\circ} \mathrm{N}$, where there is still a thinned continental crust, although there are many small isolated deeps characterised by mixed oceanic and continental crust. South of $20^{\circ} \mathrm{N}$ a linear spreading ridge formed in the Pliocene with production of MORB oceanic crust at 4.6 Ma (Cochran et al. 1986; Gaulier et al. 1988; Bayer et al. 1989; Bohannon et al. 1989; Khattab 1992; Bosworth et al. 2005; Ehrhardt et al. 2005; Almalki et al. 2014; Schettino et al. 2016). Between $19^{\circ} 30^{\prime} \mathrm{N}$ and $23^{\circ} 30^{\prime} \mathrm{N}$ a transitional zone is characterised by an attenuated continental crust injected by basaltic dykes, where ocean floor cells have nucleated but are not yet linked into a continuous axis (Cochran 1983; Pautot 1983; Bonatti et al. 1984; Bonatti 1985; Bicknell et al. 1986).

The Red Sea rifting was preceded by conspicuous volcanism in Ethiopia and southern Yemen over a 1.5 Ma time period, during which most of the basalt volcanics were produced (Mohr 
1983; Baker et al. 1996; Hofmann et al. 1997; Coulié et al. 2003; Audin et al. 2004). Starting from the Oligocene, in the Arabian margin of the Red Sea rift, Precambrian rocks experienced uplift and magmatism (intrusive and effusive) as an effect, at first, of a pre-rift mantle plume, and afterward of the asthenosphere decompression assisted by lithospheric thinning during the Red Sea opening (Pallister 1987; Coleman and McGuire 1988; Bayer et al. 1989; Camp and Roobol 1992; Daradich et al. 2003; Bosworth et al. 2005; Wilson et al. 2014). The lithospheric thinning of the Arabian-Nubian shield leading to the Red Sea opening possibly took place along inherited Pan-African structurally weak zones that are both steep and slightly oblique (N-trending) to the Red Sea axis and flat-lying shear zones (Garson and Krs 1976; Dixon et al. 1987; Makris and Rihm 1991; Ghebreab and Talbot 2000; Bosworth et al. 2005). On the other hand, the rift nucleation may have been controlled also by the interplay between plate motion driven by pulling of the Arabian slab, subducting beneath the Zagros thrust-fold belt, and the Afar plume operating a thermal weakening of the lithosphere, thus allowing localisation of deformation along the future Red Sea zone (ArRajehi et al. 2010). The activation of the Dead Sea fault zone and the westward extrusion of the Anatolia wedge during the middle Miocene and Pliocene, respectively, facilitated the northward motion of the Arabia plate that could move faster than Africa, thus aiding the rifting process (Hempton 1987; Makris and Rihm 1991; Lazar et al. 2012) that induced a renewed production of basalt in the northern Arabian plate (Ilani et al. 2001).

The onset of the lithospheric thinning heralding the Red Sea opening interrupted a tectonic and magmatic quiescence that basically lasted since the end of the Neoproterozoic. Indeed, in the region that nowadays is the Arabian shield, the Pan-African cycle ended at about $580 \mathrm{Ma}$ and was followed by widespread crustal thinning and magmatism until about $530 \mathrm{Ma}$ (Ibrahim and McCourt 1995; Genna et al. 2002; Johnson et al. 2011; Fritz et al. 2013; Veeningen et al. 2015).

\section{The Arabian shield}

The Arabian shield is located in the northern part of the East African orogen that formed during the Pan-African orogeny in the late Neoproterozoic. The Pan-African orogeny was derived by suturing East and West Gondwana to form the Gondwana super continent, as a consequence of the complete closure of the Mozambique ocean (Stern 1994; Johnson et al. 2011; Fritz et al. 2013). To the north and east, Phanerozoic sedimentary cover unconformably 
overlies the crystalline rocks of the Arabian shield. The shield consists of different terranes (e.g., Kröner 1985; Quick 1991) that along the Arabian shoulder of the Red Sea rift, from north to south, are named the Midyan, Hijaz, Jiddah, and Asir terranes (Fig. 1). The Arabian shield terranes, which consist of island arcs and micro-continents, were assembled over a period of time of about 300 million years between 890 and 580 Ma and are formed by different types of intrusive and metamorphic rock assemblages representing juvenile Neoproterozoic crust (Stoeser and Camp 1985; Vail 1985; Kröner et al. 1991; Fritz et al. 2013). In general there is no evidence of the pre-Neoproterozoic geologic record in the Arabian shield, with local exceptions such as the Khida terrane of the Afif composite terrane, the Abas and Al Mahfid terranes in western Yemen, and the Sa'al complex in the Sinai peninsula (Windley et al. 1996; Stoeser et al. 2001; Stoeser and Frost 2006; Be'eri-Shlevin et al. 2012). The Arabian shield is also characterised by gneiss belts elongated into the main fault zones that are parallel to the Red Sea axis (Johnson et al. 2011 and references therein).

The different terranes of the Arabian shield are separated by ophiolitic suture zones (Fig. 1) that formed between 780 and $600 \mathrm{Ma}$ and testify to a progressive accretion of the terranes via different subduction/collision events. Ophiolite rocks involved in the suture zones span between 870 and $630 \mathrm{Ma}$ and are associated with volcanic arc rock assemblage (Shanti and Roobol 1979; Pallister et al. 1987; Al-Saleh and Boyle 2001; Nehlig et al. 2002; Dilek and Ahmed 2003; Johnson et al. 2004; Fritz et al. 2013). The oldest ophiolites outcrop along the Yanbu and Bir Umq suture zones that are interposed between the Midyan and Hijaz terranes and Hijaz and Jiddah terranes, respectively (Fig. 1). These two suture zones are intersected at a high angle by the Red Sea rifting and thus outcrop also in the Nubian shoulder of the Red Sea rift, running up to southern Egypt-northern Sudan and central Sudan, where they are named the Heiani-Allaqi and Nakasib suture zones, respectively (Sultan et al. 1993; Abdelsalam and Stern 1996; Ali et al. 2010).

The intrusive rocks of the Arabian shield can be divided into two major groups with respect to the Pan-African orogenic history (Fig. 2). The early calc-alkaline granitoid rocks of the shield are thought to be generated in a subduction-related magmatic arc setting, whereas the youngest alkaline granitoid rocks are interpreted as being formed during the collapse of the orogen under an extensional tectonic regime (Nehlig et al. 2001; Genna et al. 2002; Hargrove et al. 2006; Farahat et al. 2007; Be’eri-Shlevin et al. 2009; Johnson et al. 2011; Fritz et al. 2013; Beyth et al. 2014; El-Bialy and Omar 2015). However, four distinct periods of 
magmatism have been identified in the western Arabian shield, as follows: Island arc about 845 Мa, syn-collisional about 736-700 Ma (mainly characterised by calc-alkaline magmatism), post-tectonic about $620 \mathrm{Ma}$, and anorogenic until about $525 \mathrm{Ma}$ (mainly characterised by alkaline magmatism) (Robinson et al. 2014). The magmatism coeval with crustal extension, postdating the Pan-African collision in the Eastern Egyptian Desert and Midyan terrane, is responsible for the formation of much of the present day crust in contrast with the rest of the shield, where the crust was produced under convergent tectonic settings (Stern et al. 1984; Clark 1985; Ibrahim and McCourt 1995). This extensional stage was also characterised by the formation of a basin filled with terrigenous sediments and connected to oceanic domains (Johnson et al. 2011).

\section{Red Sea rifting-related magmatism}

All over the Arabian shoulder of the Red Sea rift, Cenozoic volcanic plateaux (harrats) rest mostly on the Precambrian crystalline rocks and represent one of the largest Cenozoic volcanic fields in the world. Indeed, the Arabian harrats form an almost continuous roughly N-S linear volcanic belt about $3000 \mathrm{~km}$ long, from Yemen and Afar to the Bitlis suture in Turkey. In the central part of the Arabian shield, Harrats Rahat, Kishb, Khaybar and Ithnayn (Fig. 3) are N-S aligned to form the Makkah-Madinah-Nafud volcanic line. The linear distribution of this Cenozoic volcanism has been associated with a N-S trending regional lithospheric flexure that may induce a linear weak zone in the crust (Camp and Roobol 1992). Alternatively this linear distribution may be due to the N-S alignment of several mantle plumes beneath the Arabian plate (Pavoni 1992), or of a localised thermal anomaly in the mantle (Park et al. 2007). Recently it has been shown that from the Afar plume, horizontal mantle channels spread radially and one of them flows northward beneath the southern Red Sea and Arabian plate, thus most likely being responsible for thermal erosion of the base of the lithosphere and for such a linear distribution of volcanism (Hansen et al. 2007; Chang et al. 2011; Chang and Van der Lee 2011).

The age of the Cenozoic magmatic rocks of the Arabian margin lies between late Oligocene (about $30 \mathrm{Ma}$ ) and Quaternary (about 5 ka) (Fig. 4) (Camp and Roobol 1992; Bosworth et al. 2005; Al-Amri et al. 2012; Runge et al. 2016). In the Arabian margin a few historical eruptions are documented (Moufti et al. 2013) and present day magmatic activity is the cause of earthquakes linked to extensional tectonics (Pallister et al. 2010; Koulakov et al. 2014). 
Magmatism associated with seismicity has also been well documented in the Afar region (Bendick et al. 2006; Keir et al. 2006; Wright et al. 2006; Ebinger et al. 2008, 2010; Belachew et al. 2013; Desissa et al. 2013).

The development of the Cenozoic continental magmatism in Arabia is partitioned into two major stages between 30 and $20 \mathrm{Ma}$ and from $12 \mathrm{Ma}$ to the present, respectively (Camp and Roobol 1992). Until 25 Ma, magmatism developed without significant crustal extension, whereas starting from 24 Ma magmatism was coeval with strong crustal extension (Bosworth et al. 2005). Between 30 and 20 Ma magmatic rocks consist of subalkaline basalts intercalated with rhyolites, which are concentrated in the southern part of the Arabian margin, and after 12 Ma alkaline basalts are dominant and are scattered all over the Arabian margin (Schmidt et al. 1983; Manetti et al. 1991; Baker et al. 1996).

The southern Arabian margin, northern Yemen, is characterised by a first magmatic cycle between 30 and $26 \mathrm{Ma}$ with flood basalts intercalated with ignimbrites until 22 and $20 \mathrm{Ma}$ (Riisager et al. 2005). These volcanics are coeval with basaltic to granitic dykes and alkali granite emplacement between 25 and 16 Ma, and 26 and 20 Ma (Bosworth and Stockli 2016). A second and third magmatic cycle mostly consist of alkali basalts with rare alkali rhyolites and took place at about 10 Ma and after 6.5 Ma, respectively (Manetti et al. 1991).

Geochemical evidence indicates that the Yemen magmatism may result from extensive crustal contamination and fractionation processes (Manetti et al. 1991) and was fed by a plume source (Davison et al. 1994; Baker et al. 1996), which is consistent with active rifting because volcanism predates extension of the upper crust (Ghebreab 1998). In particular, Miocene to Quaternary basalts from Yemen display a higher radiogenic component with respect to basalts from further north along the Arabian margin and this may suggest that the Afar plume is responsible for the partial melting of the lithosphere beneath Yemen (Bertrand et al. 2003). Although basaltic rocks are more abundant than felsic rocks, further north, in the central coastal plain of the Arabian margin, the Ad Damm dyke suite intruded the Precambrian basement between 22 and $28 \mathrm{Ma}$ and is characterised by bimodal composition varying between alkali basalt and rhyolite (Pallister 1986, 1987; Coleman and McGuire 1988; Sebai et al. 1991). Moreover in this region Harrat Tufail consists of Miocene and Pliocene basalt and rhyolite lava flows that are blanketed by Quaternary alkali basalts (Bakhsh 2015). To explain rhyolites among the Ad Damm dykes, partial crustal melting has been proposed 
(Pallister 1987). In general fractionation and assimilation are used to explain the intrusion of rhyolitic dykes in the Jizan region, which is located south of Wadi ad Damm along the Arabian margin (Coleman and McGuire 1988). More to the north, Harrat Lunayyir is characterised by basanite, alkali olivine basalt, and trachy-basalt that are fed by a N-S trending fissure. In this case isotopic data show that there is no evidence of crustal melting and magmatic source varies throughout time with the asthenosphere rising (Duncan and AlAmri 2013). Harrat Uwayrid results from two magmatic cycles; the first during Miocene and Pliocene is dominated by alkali basalt flows; the second, Quaternary in age, is characterised by basanite and tephrites (Kaliwoda et al. 2007). At the very northern end of the volcanic belt, in Harrat Ash Shaam in Jordan, basaltic dykes are aged between 23 and 1.7 Ma. The dykes show a change in composition through time from tholeiitic, to pyroxene-olivine basalt, to olivine basalt, to basanite, marking an increase of the alkaline character (Ibrahim et al. 2003). Volcanics from Harrat Ash Shaam consist of mafic alkali basalt and basanite distributed in time over three cycles from 26 and 0.5 Ma. The Harrat Ash Shaam magmatism is interpreted as being derived from partial melting of lithospheric mantle as a consequence of lithospheric extension (Ilani et al. 2001; Shaw et al. 2003). In general, the data discussed show that Cenozoic magmatism along the western Arabian margin becomes younger northward with younger magmatic rocks being more alkaline than older magmatic rocks (Figs. 1, 3, and 4).

\section{Field outlines of the studied dykes}

Among the ten dyke samples, whose location is shown in Fig. 3, three samples consist of granitoid dykes (AP-03, AP-05, and AP-14) and two of basic dykes (AP-01 and AP-08), all intruded in the Midyan terrane rocks (Figs. 1 and 3). Other samples represent three andesite dykes intruded in the Hijaz terrane (AP-18, AP-19, and AP-20), and two rhyolite dykes that are emplaced in the Jiddah terrane, close to the tectonic contact (Ad Damm fault zone) with Asir composite terrane (AP-16 and AP-17).

Sample AP-03 and AP-05 were selected from two subvertical dykes that trend $0^{\circ} \mathrm{N}$ and $195^{\circ} \mathrm{N}$, respectively. These dykes intersect Neoproterozoic Qaraqir alkali granite of the Midyan suite, close to the tectonic contact with the Atiyah monzogranite (Grainger and Hanif 1989). The age of the Qaraqir formation lies between $630 \mathrm{Ma}$ and $609 \mathrm{Ma}$ (Al-Husseini 2015). Sample AP-14 is from Wadi al Hayil, which corresponds with a dextral fault. This 
subvertical dyke trends $352^{\circ} \mathrm{N}$ and intrudes gabbroic rocks not far from the boundary with an amphibole-bearing tonalite, both belonging to the Neoproterozoic Nabt complex (Pellaton 1982). The Nabt complex was intruded by the Salajah tonalite at $725 \pm 12$ Ma (Pallister et al. 1987).

Sample AP-01 is located in the same area as samples AP-03 and AP-05, near Jabal Masah, and it is part of a subvertical dyke swarm trending $317^{\circ} \mathrm{N}$ (Fig. 5a). The dyke swarm intruded the Neoproterozoic alkali granite of the Massah complex, which is dated at $629 \pm 12 \mathrm{Ma}$ (Grainger and Hanif 1989). The locality is in the proximity of a $120^{\circ} \mathrm{N}$ trending fault that put the alkali granites in contact with Neoproterozoic volcanoclastic rocks of the Bayda complex (Grainger and Hanif 1989). Sample AP-08 represents a subvertical dyke trending $277^{\circ} \mathrm{N}$ to the north of Wadi Marabit and Wadi ar Ramah, only $6.5 \mathrm{~km}$ from the Red Sea shore. This dyke is intruded in the Neoproterozoic monzogranite of the Liban complex, which is part of the Marabit suite (Davies 1985). The Liban monzogranite is dated at $621 \pm 7$ Ma or $638 \pm 10$ Ma (Hedge, in Al-Husseini 2015). This dyke shows a marked morphology that shapes a hill in the middle of the wadi plain filled with Quaternary sediments (Fig. 5b).

Samples AP-18, AP-19, and AP-20 are from Wadi Jari, $5 \mathrm{~km}$ west from the intersection with Wadi Rakhu. These are subvertical dykes (Fig. 5c and 5d) trending $255^{\circ} \mathrm{N}, 170^{\circ} \mathrm{N}$, and $302^{\circ} \mathrm{N}$, respectively and are intruded into a Neoproterozoic granitoid complex consisting of alkali granite, monzogranite, and granodiorite (Pellaton 1979).

Samples AP-16 and AP-17 are from $1.5 \mathrm{~km}$ southwest of Bir ad Damm village. These represent two subvertical dykes trending $28^{\circ} \mathrm{N}$ and $0^{\circ} \mathrm{N}$, intruded into the Neoproterozoic meta-basalts of the Baish group, whose protoliths are older than $804 \mathrm{Ma}$. Here the dykes and country rocks are affected by the Ad Damm fault zone that put them in contact with the Neoproterozoic granite gneiss of the Namam complex (Pallister 1986). These two dykes show a good morphological expression and are responsible for tracing the hill ridges that are continuous for about $10 \mathrm{~km}$ (Fig. 5e and 5f).

\section{Microstructural and petrographical analysis}


Microstructural and petrographical analysis has been applied to the dyke samples in order to integrate the field data collected in 2015. Besides the optical microscope, samples have been analysed in part also by means of a scanning electron microscope (SEM). In the following, granitoid, basic, andesitic, and rhyolitic dykes are described separately.

\section{Granitoid dykes}

The coarse-grained granitoid dykes consist of granite (AP-03), monzogranite (AP-05), and granodiorite (AP-14). The main forming minerals are quartz, K-feldspar, plagioclase, and biotite. Accessory minerals consist of medium to fine-grained opaque minerals, zircon, apatite, and rutile. These minerals constitute the magmatic phases that are altered by postmagmatic mineral phases such as white mica and chlorite. Rocks show holocrystalline hypidiomorphic granular texture. According to modal analysis, K-feldspar (40 - $30 \%)$ is more abundant than plagioclase $(10-20 \%)$ with the exception of sample AP-14 where plagioclase (35\%) is more abundant than K-feldspar (10\%). K-feldspar mostly forms euhedral to subhedral crystals and shows perthite and minor flame perthite exsolution of albite in sample AP-03 and microcline twinning in sample AP-05 (Fig. 6a). At the margins of K-feldspar phenocrysts graphic intergrowths of K-feldspar and quartz occur (AP-03); the graphic intergrowth may also consist of sub-rounded quartz crystals that testify that, after complete crystallisation, graphic structure recrystallized (cf., Vernon 2004) (Fig. 6b). Plagioclase forms medium- to coarse-grained subhedral crystals and locally shows polysynthetic twinning. In sample AP-05 plagioclase forms aggregates with K-feldspar or is enclosed in coarse-grained K-feldspar phenocrysts (Fig. 6c). Often both plagioclase and Kfeldspar are altered by a very fine-grained aggregate of white mica and minor chlorite and epidote (Fig. 6c). In sample AP-03 such alteration is so intense that locally it makes optical distinction of plagioclase and K-feldspar difficult. Locally the outer rims of plagioclase survived the prominent replacement by white mica, chlorite, and epidote (Fig. 6d) suggesting that the plagioclase rims may be poorer in Ca. Quartz forms mostly medium- to coarsegrained sub-rounded anhedral crystals that show homogeneous extinction or only a weak undulose extinction. In sample AP-14 quartz shows a more evident undulose and subgranular extinction than in the other granitoid rock samples. Although in general it records a gentle deformation, quartz is the only completely pristine major forming magmatic mineral. Locally quartz forms rounded crystals surrounded by interstitial K-feldspar (Fig. 6e). Biotite occurs in all three samples and forms medium-grained crystals that are often pervasively replaced by 
chlorite, white mica, and fine-grained opaque minerals. The minerals replacing biotite grew mimetically along cleavages and locally overgrow entirely single grains. Locally chlorite constitutes layers of randomly oriented crystals (e.g., AP-03), which may be due to fluid circulations during the late stage of crystallisation or after the complete crystallisation. In sample AP-14 coarse-grained green poikilitic hornblende crystals occur (Fig. 6f). These crystals enclose rounded quartz grains and fine-grained biotite and are associated with coarsegrained biotite aggregates and zircon grains. In these aggregates biotite shows slight undulose extinction. Apatite forms fine-grained crystals enclosed in K-feldspar. Among accessory minerals titanite occurs in AP-03 and forms very fine-grained sub-rounded crystals enclosed in quartz.

\section{Basic dykes}

Samples AP-01 and AP-08 consist of basaltic dykes that show intergranular and porphyritic texture, respectively. Both dykes contain euhedral (AP-08) and subhedral (AP-01) plagioclase phenocrysts that are less than $1 \mathrm{~mm}$ and up to $5 \mathrm{~mm}$ in size in AP-01 and AP-08, respectively (Fig. 7a). Plagioclase also forms interstitial grains (AP-01) and euhedral microlites in the groundmass (AP-08). In both samples plagioclase shows growth polysynthetic twinning and zoning. In sample AP-01 plagioclase phenocrysts are replaced by fine-grained white mica, which forms randomly oriented aggregates affecting especially the crystal core and leaving the very outer rim unaltered (Fig. 7b). Groundmass plagioclase survived white mica alteration. In contrast, in sample AP-08 plagioclase is very pristine (Fig. 7a). The mafic mineral phases consist of brown amphibole, pyroxene, olivine, and rare biotite. Amphibole is more abundant in AP-01 than in AP-08. In sample AP-01 amphibole forms euhedral grains up to $0.1 \mathrm{~mm}$ in size, just bigger than the groundmass (Fig. 7b). Locally, amphibole encloses acicular apatite crystals. Rarely amphibole is rimmed by calcite, Fe-Mg-carbonates (determined by the SEM analysis), and chlorite. In AP-08 amphibole forms up to $0.5 \mathrm{~mm}$-sized euhedral phenocrysts rimmed by coronitic aggregates of very finegrained Fe-oxide (Fig. 7c), which replace almost entirely amphibole. This coronitic aggregate may result from disequilibrium between amphibole and liquid either because of liquid changing composition during crystallisation or amphibole being a xenocryst. Clinopyroxene forms elongated crystals in sample AP-01 (Fig. 7d) that locally are partially enclosed in amphibole. In AP-08 pyroxene consists of more abundant clinopyroxene than orthopyroxene. Clinopyroxene forms euhedral medium-grained crystals scattered in the groundmass and up 
to $4 \mathrm{~mm}$ sized crystals (Fig. 7e). Medium-grained crystals contain fine-grained ilmenite and apatite. Orthopyroxene occurs in rounded crystals scattered in the groundmass, enclosed in plagioclase phenocrysts (Fig. 7a), and enclosed in and aggregate with the large clinopyroxene crystals (Fig. 7e). Olivine occurs only in sample AP-01 as rounded crystals scattered in the rock matrix. Normally olivine grains are up to $0.5 \mathrm{~mm}$ in size with the exception of few mmsized grains. Olivine shows a zoned rim that is partially replaced by serpentine and talc. In sample AP-08 mm-sized phenocrysts that are totally replaced by talc/serpentine and carbonates may represent former olivine. This kind of replacement occurs also within coarsegrained aggregates of clinopyroxene. Biotite occurs only in AP-01 in the form of a few $\mu$ msized crystals in contact with olivine or its rimming reaction products. Sample AP-01 is characterised by a few mm-sized whitish aggregates consisting of very large-grained euhedral calcite and analcime (Fig. 7f). Analcime contains rare fine-grained K-feldspar, epidote, chlorite, and quartz. Glass is still preserved in sample AP-08 and in plane polarised light it looks yellowish. It is enclosed in coarse-grained plagioclase phenocrysts, both in the cores and rims (Fig. 7a), and is interstitial within plagioclase microlites of the groundmass. Medium-grained internal strain-free plagioclase laths show shape-preferred orientation (Fig. 7c and 7e). This evidence is consistent with a magmatic fluidal structure that wraps around plagioclase, clinopyroxene, and olivine phenocrysts. In AP-08 the fluidal structure is defined also by shape preferred orientation of clinopyroxene, and minor amphibole (Fig. 7c).

\section{Andesitic dykes}

AP-18, AP-19, and AP-20 dykes of intermediate composition are strongly altered and often recognising the original magmatic minerals and textures is difficult. These dykes are characterised by a porphyritic texture that is more evident in AP-18 and AP-20 and is defined by very altered plagioclase phenocrysts, and amphibole (Fig. 8a). Some of the mineral phases are recognizable by their shape and alteration products. Plagioclase phenocrysts are generally totally replaced by fine-grained aggregates of white mica and minor epidote. Amphibole (hornblende) phenocrysts are replaced by green amphibole (actinolite) and chlorite. Plagioclase also occurs as fine-grained laths that locally (AP-20) show shape-preferred orientation defining a fluidal structure. In the latter case, plagioclase shows polysynthetic growth twinning. Generally, the lath-shaped plagioclase crystals are only partially replaced by fine-grained white mica and epidote (Fig. 8b). Locally zoned interstitial grains of plagioclase are intergrown with albite and minor K-feldspar (Fig. 8c). In particular, K- 
feldspar occupies grain boundaries or forms skeletal microlites. Besides plagioclase, clinopyroxene is another surviving magmatic mineral (e.g., AP-18), along with minor euhedral and lozenge-shaped titanite crystals (e.g., AP-20). Clinopyroxene shows fractures filled by chlorite (Fig. 8d). Quartz and magnetite are pristine and form interstitial and euhedral crystals, respectively. Quartz shows undulose extinction that testifies to the effect of crystal plastic strain. In AP-18 fine-grained aggregates of white mica, epidote, and albite and green amphibole (actinolite), chlorite, and calcite totally replaced large phenocrysts. In AP-19 the phenocrysts are totally replaced by fine-grained chlorite aggregates with a rim of white mica. Fine-grained chlorite and epidote are diffused all over the rock matrix, likely as replacement of the original groundmass minerals. Epidote also forms rounded coarse-grained aggregates. Late-stage micro-veins, filled by calcite and minor chlorite, intersect the rock groundmass.

\section{Rhyolitic dykes}

AP-16 and AP-17 are inequigranular porphyritic rhyolitic dykes containing K-feldspar phenocrysts less than $1 \mathrm{~mm}$ in size. These euhedral phenocrysts locally are grouped into aggregates (Fig. 9a) and show Carlsbad twinning and ubiquitously are rich in perthitic exsolution of albite (Fig. 9b). Perthitic albite forms blebs that are slightly elongated. The groundmass consists of up to $0.1 \mathrm{~mm}$ long crystals of K-feldspar, albite, quartz, and minor magnetite. Euhedral to subhedral K-feldspar in the rock matrix contains perthitic albite and displays a weak shape preferred orientation, especially in sample AP-16. Albite and quartz occur as interstitial grains in the rock matrix and are of roughly the same size as K-feldspar in the matrix. Magnetite forms euhedral to subhedral crystals diffused in the rock matrix (Fig. 9b). Magnetite that also grew in patches occurs within K-feldspar phenocrysts. In the latter case magnetite forms very fine-grained crystals (Fig. 9b) giving to K-feldspar a mottled appearance. However, K-feldspar can still be recognized locally by its distinct shape. In AP17, along with magnetite, rare calcite patches also overgrew K-feldspar. Quartz occurs in the groundmass and forms subhedral or interstitial crystals (Fig. 9b) that show very weak undulose extinction.

\section{U-Pb geochronology}

\section{Analytical methods}


We acquired preliminary $\mathrm{U}-\mathrm{Pb}$ data in order to test the age of three granitoid dykes (AP-03, AP-05, and AP-14) that were selected because they contain zircon grains larger than $25 \mu \mathrm{m}$. $\mathrm{U}-\mathrm{Pb}$ geochronology was carried out on zircon grains in polished thin section at the CNRIGG UOS of Pavia (Italy) with Laser Ablation (LA)-ICP-MS (Table 1). The system couples an ArF excimer laser microprobe (type GeoLas102 from MicroLas) with a sector field ICPMS (type Element from ThermoFinnigan).

The signals of ${ }^{202} \mathrm{Hg},{ }^{204}(\mathrm{~Pb}+\mathrm{Hg}),{ }^{206} \mathrm{~Pb},{ }^{207} \mathrm{~Pb},{ }^{208} \mathrm{~Pb},{ }^{232} \mathrm{Th}$ and ${ }^{238} \mathrm{U}$ masses were acquired. ${ }^{202} \mathrm{Hg}$ is acquired to correct the isobaric interference of ${ }^{204} \mathrm{Hg}$ on ${ }^{204} \mathrm{~Pb}$, so that the presence of common $\mathrm{Pb}$ in the sample can be monitored. However, the background of mass 204 is relatively high, due to traces of $\mathrm{Hg}$ in the He gas, and does not allow us to determine small amounts of common $\mathrm{Pb}$. Remarkably, in the investigated samples the signal of ${ }^{204}(\mathrm{~Pb}+\mathrm{Hg})$ was always indistinguishable from the background. The ${ }^{235} \mathrm{U}$ signal is calculated from ${ }^{238} \mathrm{U}$ on the basis of the ratio ${ }^{238} \mathrm{U} /{ }^{235} \mathrm{U}=137.818$ (Hiess et al. 2012).

U-Pb fractionation effects in zircon were simultaneously corrected using a matrix matched external standard and considering the same integration intervals on the standard and the unknowns. Analyses were carried out using a spot size of $25 \mu \mathrm{m}$, a frequency of $5 \mathrm{~Hz}$ and a laser fluence of $8 \mathrm{~J} \mathrm{~cm}^{-2}$. The reference zircon GJ-1 (Jackson et al. 2004) was adopted as the external standard and the reference zircon 02123 (Ketchum et al. 2001) was selected as the validation standard (Table 2). Data reduction was carried out with the software package GLITTER ${ }^{\circledR}$ (Van Achterbergh et al. 2001). Individual uncertainties given by the software for the isotope ratios were propagated relative to the respective reproducibility of the standard. This procedure was carried out for each analytical run as reported in Horstwood et al. (2003). The ISOPLOT/Ex 3.00 software package by Ludwig (2003) was used for U-Pb apparent age calculations and representations.

\section{LA-ICP-MS U-Pb dating results}

Before U-Pb dating, zircon grains were localized at the SEM by acquiring BSE images of the textural site (Fig. 10). Zircon commonly occurs as euhedral to subhedral grains; inclusions are common and fractures, with or without fragment displacement, are also frequent. In the BSE images, zircon grains revealed zoning features, that locally are oscillatory (Fig. 10b, c, d 
and f). These features are coherent with the magmatic origin of the zircon grains. U-Pb isotopic data and calculated ages of samples and standards are reported in Table 1 and Table 2, respectively. Eighteen analyses on seventeen zircon grains were collected for sample AP-

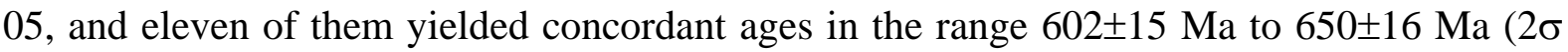
error, Fig. 11). Nineteen analyses on fourteen zircon grains were collected for sample AP-03; $\mathrm{U}-\mathrm{Pb}$ results were mainly discordant with only six concordant data at $604 \pm 22 \mathrm{Ma}, 689 \pm 24$ Ma, 732 \pm 25 Ma, 735 \pm 28 Ma, 748 \pm 27 Ma and 805 \pm 30 Ma (Fig. 11). Only one zircon grain was analysed for the sample AP-14 and the two analysis results were concordant at $724 \pm 18$ Ma and 792 \pm 21 Ma (Fig. 11).

Since this preliminary geochronological investigation revealed ages concerning the Arabian shield history, we did not proceed with a quantitative data acquisition on zircon separates, as usually it is done for geochronological investigation of intrusive rocks. Even though the emplacement ages cannot be constrained from the collected data, U-Pb results suggest a Neopreterozoic origin for the investigated samples. Tentatively, we can envisage an intrusive age between late Cryogenian and early Ediacaran for the AP-05 dyke, whereas the scattered concordant U-Pb data obtained for samples AP-03 and AP-14 might be due to the inheritance signature of the country rocks related to the complex tectonic history of the Arabian shield.

\section{Mineral chemistry}

Mineral chemical compositions were acquired by energy dispersive X-ray spectroscopy (EDS) analysis performed using the Cambridge Stereoscan 360 scanning electron microscope (SEM) of CNR Milano (Italy), operating at the Earth Science Department of Milano University. Six dyke samples were analysed: Two basaltic (AP-01 and AP-08), two andesitic (AP-18 and AP-19) and two rhyolitic (AP-16 and AP-17) dykes. Mineral stoichiometric formulae were recalculated from the weight percent of element oxides on the basis of the following numbers of oxygen atoms: 4 for olivine and spinel, 6 for pyroxene, 7 for serpentine, 8 for feldspars, 12.5 for epidote, 22 for biotite, white mica, and talc, 23 for amphibole, 28 for chlorite. $\mathrm{Fe}^{3+}$ was recalculated for epidote, pyroxene, amphibole, and spinel on the basis of charge balance. In particular, for pyroxene, amphibole, and spinel, the calculation schemes of Morimoto (1988), Locock (2014), and Droop (1987) were followed, 
respectively. Hereafter the compositional variation of each mineral phase is described in comparison with the different samples and in relation to the microstructural site.

Amphibole (Table 3) has been analysed in two basaltic dykes (samples AP-01 and AP-08) and in one andesitic dyke (sample AP-18). Amphibole in sample AP-08 shows the highest content in $\mathrm{Na}$ that is variable between 0.95 and 1.06 atoms per formula unit (a.p.f.u.) and the lowest in Ca that varies between 1.82 and 1.85 a.p.f.u. In contrast, amphibole in sample AP18 shows the highest $\mathrm{Ca}$ (1.50-2.00 a.p.f.u.), and the lowest $\mathrm{Na}$ (0.11 and 0.68 a.p.f.u.) concentration. Amphibole in AP-01 shows intermediate values of Na (0.53-0.56 a.p.f.u.) and Ca (1.89-197 a.p.f.u.) with respect to amphibole in samples AP-08 and AP-18 (Fig. 12a). However, amphibole in AP-01 reaches the highest content in Al (1.86-2.72 a.p.f.u.) and Ti (0.42-0.62 a.p.f.u.), with maximum values recorded in the core of the grains. $\mathrm{Al}(0.46-1.47$ a.p.f.u.) and $\mathrm{Ti}$ (0.01-0.44 a.p.f.u.) contents show the lowest values in amphibole from sample AP-18 (Fig. 12b). Amphibole in sample AP-08 has an intermediate composition of Al (2.07-2.23 a.p.f.u.) and $\mathrm{Ti}(0.40-0.46$ a.p.f.u.) with respect to amphibole in samples AP-01 and AP-18 (Fig. 12b). In sample AP-18 amphiboles forming both phenocrysts and matrix crystals are mostly actinolite. Since the sample is affected by a strong alteration, it is suggested that the actinolite derives from the alteration of primary amphibole (hornblende). Amphibole from samples AP-01 and AP-08 shows Si content between 5.67 and 6.33 a.p.f.u. and between 6.11 and 6.12 a.p.f.u. and $\mathrm{Mg}$ content between 1.87 and 2.48 a.p.f.u. and 2.93 and 3.13 a.p.f.u., respectively.

Clinopyroxene and orthopyroxene (Table 4) have been analysed in samples AP-01, AP-08, and AP-18 and consist of augite and diopside, and enstatite, respectively (Fig. 12c). Clinopyroxene in sample AP-01 is the richest in Ca (0.92-0.94 a.p.f.u.) and consists of diopside. The Ca in clinopyroxene in samples AP-08 (0.74-0.89 a.p.f.u.) and AP-18 (0.790.83 a.p.f.u.) has similar concentrations and is consistent with pyroxene having an augite composition. In sample AP-08 only one core of a crystal defining the fluidal structures has diopside composition. In the same sample, finer-grained augite grains defining the fluidal structure show the lowest content in $\mathrm{X}_{\mathrm{Mg}}\left(\mathrm{Mg} /\left(\mathrm{Mg}+\mathrm{Fe}^{2+}\right)\right)$ and $\mathrm{Ca}$, whereas coarse-grained augite grains record the highest $\mathrm{X}_{\mathrm{Mg}}$ (Fig. 12d). $\mathrm{X}_{\mathrm{Mg}}$ is lower and similar in clinopyroxene from samples AP-01 and AP-18 and it is higher in the grain core in both samples (Fig. 12d). Orthopyroxene (sample AP08) shows the highest $\mathrm{X}_{\mathrm{Mg}}$ ratio $(0.78-0.82)$ in grains associated 
with the coarse grained clinopyroxene, whereas crystals in the rock matrix and enclosed in plagioclase phenocrysts show $\mathrm{X}_{\mathrm{Mg}}$ ranging between 0.68 and 0.77 (Fig. 12d).

Feldspar (Table 5) was analysed in all samples and consists of plagioclase and alkali feldspar (Fig. 12e). Coarser-grained plagioclase from sample AP-01 reaches the highest content in anorthite (An) and plots in the compositional field of bytwonite (An = 72-78\%). These crystals show a rim of oligoclase. In the same sample, finer-grained euhedral laths shows a labradoritic composition $(\mathrm{An}=57 \%)$, whereas interstitial plagioclase mostly consists of oligoclase and minor albite (An = 2-14\%). In sample AP-08 the composition of plagioclase varies from labradorite to oligoclase. Most of the plagioclase crystals in this sample show an andesinic composition, such as the coarse-grained phenocrysts (An $=40-43 \%$ ). Finer-grained crystals show a similar composition with anorthite varying from $40 \%$ and $42 \%$. The highest anorthite content is reached by plagioclase crystals enclosed in amphibole ( $\mathrm{An}=58 \%$ ) and coarse-grained pyroxene $(\mathrm{An}=46 \%)$. The plagioclase microlites preserved in micro-glass pockets show an anorthite content between 20\% and 32\%. In sample AP-18 plagioclase shows andesinic and albitic composition. Andesinic plagioclase forms fine-grained crystals in the rock matrix and shows an increase of anorthite from core (33\%) to rim (47\%). Albitic plagioclase forms interstitial crystals and shows content in anorthite variable between $1 \%$ and $10 \%$. In this sample K-feldspar microlites show content in orthoclase between 93\% and 97\%. Sample AP-19 (andesite) shows plagioclase with composition varying from labradorite to albite. A few dozen micron-sized laths show anorthite variable between $58 \%$ and $65 \%$ with a few exceptions of $29 \%$ anorthite. These laths show a rim of albite with an anorthite content of 10\%. Samples AP-16 and AP-17 (rhyolite) contain only alkali feldspar that consists of orthoclase and albite (Fig. 12e). In sample AP-17 K-feldspar phenocrysts and microlites are $100 \%$ orthoclase, whereas in sample AP-16 K-feldspar phenocrysts and microlites show content of orthoclase ranging between $96 \%$ and $97 \%$. Both in K-feldspar phenocrysts and laths, perthitic exsolution shows albite contents varying from 95\% and 99\%, with the exception of a few cases in which perthite consists of $78 \%$ of albite and $22 \%$ of orthoclase. This last example may suggest that locally the subsolidus unmixing is not complete. Finegrained albite in the rock matrix consists of $98 \%$ and $99 \%$ of albite.

Olivine (Table 6) occurs only in sample AP-01 (basalt) and shows an $\mathrm{X}_{\mathrm{Mg}}$ variable between 0.69 and 0.81 , with lower values detected from crystal rims. Higher amount of iron in olivine rims than cores suggest that olivine crystallised during changes in residual melt composition. 
Biotite (Table 6) was analysed in sample AP-01 as well and is characterised by $\mathrm{X}_{\mathrm{Mg}}$ between 0.40 and 0.51 , with lower values characterising biotite in fine-grained acicular grains and higher values in biotite facing the coronitic reaction product of olivine destabilisation.

Spinel consists of magnetite with an $\mathrm{X}_{\mathrm{Fe}}{ }^{3+}\left(\mathrm{X}_{\mathrm{Fe}}^{3+} /\left(\mathrm{X}_{\mathrm{Fe}}{ }^{3+}+\mathrm{Cr}+\mathrm{Al}\right)\right)$ ratio varying between 0.91 and 0.99 (Fig. 13a). In basaltic and andesitic dyke samples (AP-08 and AP-19, respectively) magnetite shows significant $\mathrm{Ti}$ content of 0.28 and 0.19 a.p.f.u., respectively (Fig. 13b). In samples AP-16 and AP-17 (rhyolite dykes) magnetite forming euhedral crystals in the rock matrix shows the highest values of $\mathrm{X}_{\mathrm{Fe}}{ }^{3+}$ compared to very fine-grained magnetite occurring in patches within K-feldspar phenocrysts. These magnetite patches contain higher $\mathrm{X}_{\mathrm{Cr}}\left(\mathrm{Cr} /\left(\mathrm{Cr}+\mathrm{X}_{\mathrm{Fe}}^{3+}+\mathrm{Al}\right)\right)(0.06)$ than euhedral crystals (0.00-0.03).

Chlorite (Table 6) plots in the compositional field of pycnochlorite with minor compositions in the field of diabanite in sample AP-01 (Fig. 13c). In samples AP-18 and AP-19 (andesitic dyke) $\mathrm{X}_{\mathrm{Fe}}$ varies between 0.43 and 0.49 , with the highest values recorded in lamellae that overgrew amphibole phenocrysts and lower values in fine grained aggregates that completely replaced former phenocrysts. Si comprises between 5.76 and 6.24 a.p.f.u. and characterises chlorite associated with epidote aggregates and that overgrew the rock matrix, respectively. Chlorite in sample AP-01 shows lower $\mathrm{X}_{\mathrm{Fe}}$ and much higher Si than in samples AP-18 and AP-19 (Fig. 13c).

Epidote (Fig. 13d, Table 4) was analysed in samples AP-18 and AP-19 (andesitic dyke) and shows a composition characterised by an $\mathrm{X}_{\mathrm{Fe}}{ }^{3+}\left(\mathrm{Fe}^{3+} /\left(\mathrm{Fe}^{3+}+\mathrm{Al}^{\mathrm{VI}}+\mathrm{Cr}+\mathrm{Ti}\right)\right)$ varying between 0.28 and 032, with higher values obtained from sample AP-18. The only exception is a crystal core in which iron is very low $\left(\mathrm{X}_{\mathrm{Fe}}{ }^{3+}=0.02\right)$.

White mica (Table 6) has Si content between 6.11 and 6.58 a.p.f.u., Al between 4.64 and 5.73 a.p.f.u., and $\mathrm{Fe}+\mathrm{Mg}$ between 0.15 and 1.08 a.p.f.u. (Fig. 13e). The highest and lowest values are recorded in sample AP-19 (andesitic dyke) in grains associated with fine-grained epidote. White mica with the lowest $\mathrm{Si}$ value shows the lowest $\mathrm{Fe}+\mathrm{Mg}$ and highest $\mathrm{Al}$ values. Sample AP-18 records the lowest Al value in white mica forming fine-grained aggregates with epidote diffused in the rock matrix. The highest $\mathrm{Fe}+\mathrm{Mg}$ value is recorded in in white mica replacing coarse-grained plagioclase phenocrysts in sample AP-01, although, in this sample, white mica shows values as low as 0.33 and 0.66 a.p.f.u. Paragonite content is mostly 
zero and is detected in white mica from sample AP-18 $\left(\mathrm{X}_{\mathrm{Pg}}=0.02-0.03\right)$ in grains replacing plagioclase. The content in muscovite is higher than that of paragonite, according to $\mathrm{X}_{\mathrm{Ms}}$ (Green and Usdansky 1986) that varies between 0.62 and 0.96 (Fig. 13f). The lowest $\mathrm{X}_{\mathrm{Ms}}$ values are recorded in white mica replacing plagioclase in sample AP-01 and the highest values in white mica associated with epidote in sample AP-19.

Serpentine and talc form the coronitic reaction products that rim olivine in sample AP-01. Serpentine shows an $\mathrm{X}_{\mathrm{Mg}}$ ratio of 0.85 and in talc the $\mathrm{X}_{\mathrm{Mg}}$ ratio varies between 0.64 and 0.76. In sample AP-08 talc is associated with carbonates, forms the reaction product of coarsegrained completely replaced phenocrysts, and domains enclosed in coarse-grained clinopyroxene probably representing former olivine. In this sample talc is characterised by an $\mathrm{X}_{\mathrm{Mg}}$ value varying between 0.65 and 0.74 .

Glass (Table 7) occurs only in sample AP-08 (basaltic dyke) and shows a variable composition in different microstructural sites. Glass trapped within both core and rim of plagioclase phenocrysts shows the highest $\mathrm{SiO}_{2}, \mathrm{Na}_{2} \mathrm{O}$, and $\mathrm{K}_{2} \mathrm{O}$ contents, although plagioclase phenocrysts also enclose glass with 68 weight percent of $\mathrm{SiO}_{2}$ and 0.5 weight percent of $\mathrm{Na}_{2} \mathrm{O}+\mathrm{K}_{2} \mathrm{O}$. Glass with similar composition occurs also in the groundmass of nearby plagioclase phenocrysts. Glass with high $\mathrm{SiO}_{2}$ also occurs in the groundmass next to amphibole and clinopyroxene.

\section{Whole rock geochemistry}

Seven samples were sent for whole rock geochemistry analysis to Activation Laboratories in Ancaster, Ontario, Canada. Major and trace elements (Table 8) were analysed via lithium metaborate/tetraborate fusion with ICP and ICP/MS (inductively coupled plasma mass spectrometry).

The TAS (total alkali versus silica) diagram reveals that basic dyke samples AP-01 and AP08 consist of basanite to basalt, respectively (Fig. 14). Intermediate dyke samples AP-18, AP19, and AP-20 have andesitic composition and in particular sample AP-19 is basaltic andesite, sample AP-20 is trachyandesite, and sample AP-18 is andesite. Acidic dyke samples AP-16 and AP-17 are subalkaline rhyolite (Fig. 14). In the TAS diagram, data from Cenozoic magmatic rocks from different localities of the Arabian plate are compared with the data 
presented in this chapter (Fig. 14). Samples AP-01 and AP-08 plot in the alkaline field and show a similar composition to volcanic rocks from Harrat Lunayyir (Duncan and Al-Amri 2013), the Jordanian part of the Harrat Ash Shaam, which are younger than 8 Ma (Shaw et al. 2003), and from a region $100 \mathrm{~km}$ south of Aleppo in Syria (Krienitz et al. 2009). Andesitic samples show a composition quite close to that of magmatic rocks from the central coastal plain of Arabia. Samples AP-18 and AP-19 have a composition quite close to that of dykes of the Gumayqah complex, which are dated between 21 and 24 Ma (Pallister 1987), and sample AP-20 shows a composition quite close to that of Burgatinah diorite (Pallister 1987). Samples AP-16 and AP-17 are from dykes close to the Ad Damm fault zone and they display a similar composition to other dykes and volcanic rocks of the Sita formation. At Jabal Sita, which is located about $25 \mathrm{~km}$ west from sampling sites of samples AP-16 and AP-17, rhyolites have been dated between 19 and 20 Ma (Pallister 1987).

In the classification diagram involving $\mathrm{Zr}, \mathrm{TiO}_{2}, \mathrm{Y}$, and $\mathrm{Nb}$ (Winchester and Floyd 1977), AP-01 and AP-08 samples plot in the field of alkaline basalt, samples AP-18 and AP-20 plot in the field of andesite, and sample AP-19 is in the field of andesite basalt (Fig. 15a). These plots are consistent with the data plotted in the TAS diagram. The sole exception concerns sample AP-20 that plots in the field of andesite, whereas in the TAS diagram it plots in the field of trachyandesite. Basic and intermediate dykes are also plotted in a diagram that relates Th and Nb (Saccani 2015), which are normalised with respect to the normal MORB (mid ocean ridge basalt) composition (Sun and McDonough 1989). Samples AP-01 and AP-08 are classifiable as alkaline ocean-island basalt, although sample AP-08 falls also in the compositional field of plume-type MORB and enriched-type MORB. Samples AP-18 and AP-19 plot in the compositional field of calc-alkaline basalts, whereas sample AP-20 is classifiable as back arc basin basalt or low-Ti island arc tholeiite (Fig. 15b). According to the classification diagram of Saccani (2015), the composition of samples AP-01 and AP-08 is consistent with a divergent tectonic setting, whereas the composition of samples AP-18, AP19 , and AP-20 is consistent with a convergent tectonic setting.

The rhyolitic dykes AP-16 and AP-17 in the diagram that relate both $\mathrm{FeO}^{\text {tot }} /\left(\mathrm{FeO}^{\text {tot }}+\mathrm{MgO}\right)$ and $\mathrm{Na}_{2} \mathrm{O}+\mathrm{K}_{2} \mathrm{O}-\mathrm{CaO}$ with $\mathrm{SiO}_{2}$ (Frost et al. 2001) are classifiable as alkali and alkalicalcic ferroan A-type granites (Fig. 16a and 16b). Moreover, on the binary diagram Rb/Nb versus Y/Nb (Eby 1992) the samples AP-16 and AP-17 plot in the field of A-type granites characteristic of continental rifting or intraplate magmatism (Fig. 16c). 
Finally, in the AFM diagram (Fig. 17) most of the samples plot in the calcalkaline field. Only a basic (AP-01) and intermediate (AP-19) dyke samples plot over the divide of the calcalkaline and tholeiitic fields. The sole sample that definitely plots in the tholeiitic field is AP-08. The dyke samples of basic and intermediate composition that plot in the calcalkaline field may have recorded contamination with crustal material.

\section{Discussion and conclusions}

Microstructural and geochemical features of dykes that have been sampled along the Arabian Red Sea margin, between the Al Lith and Tabuk regions (Fig. 3) are here summarised. Microstructural analysis shows that generally the texture developed during the magmatic emplacement of the dykes and that post-magmatic crystal-plastic deformation is quite scarce. According to the slight undulose extinction, the mineral phase that records the highest amount of post-magmatic internal strain is quartz, mostly in granitoid but also in andesitic dykes. Feldspars, contain growth twinning and are deformation twinning-free. The sole microstructure in alkali feldspar imputable to post-magmatic tectonics is the albite flame perthite that occurs rarely in granitoid dykes (sample AP-14) and testifies to unmixing assisted by differential stress (Pryer and Robin 1996). Since quartz may be affected by crystal plasticity under low temperatures (e.g., Stipp et al. 2002) and feldspar does not show clear evidence of internal strain, the weak crystal plastic deformation in quartz should have been recorded at temperatures below $400^{\circ} \mathrm{C}$ (e.g., Passchier and Trouw 2005). The highest amount of internal strain in quartz is recorded in the granitoid dykes, in particular in the sample AP14, whereas in andesitic dykes, quartz shows gentle undulose extinction. In granitoid dykes graphic intergrowth between K-feldspar and quartz testifies that the two minerals crystallised together under cotectic conditions (e.g., Vernon 2004). Similarly, the mineral composition of rhyolitic dykes, which basically consists of K-feldspar, quartz, and albite, is consistent with minimum-temperature composition of a much-differentiated granitic system.

The dykes show either massive or oriented texture. The granitoid dykes are coarse-grained holocrystalline rocks and record massive texture, whereas oriented texture is evident in some of the mafic dykes and it is poorly defined in the rhyolitic dykes. Generally, shape-preferred orientation of euhedral and strain-free crystals (mostly plagioclase) defines the oriented texture. These characteristics are consistent with this texture being interpreted as a magmatic 
fluidal structure (Paterson et al. 1989). In mafic dykes, the fluidal structure is defined in general by plagioclase crystals and in rhyolitic dykes by K-feldspar. In particular, in sample AP-08 the fluidal structure is defined by clinopyroxene and amphibole medium-grained phenocrysts and plagioclase microlites that wrap around plagioclase and clinopyroxene coarse-grained phenocrysts. This evidence suggests that coarse-grained phenocrysts may have started growing earlier than the other crystals. This interpretation is also consistent with coarse-grained plagioclase phenocrysts having a higher content in anorthite with respect to groundmass plagioclase microlites and with a higher $\mathrm{X}_{\mathrm{Mg}}$ ratio in coarse- and mediumgrained clinopyroxene than in groundmass clinopyroxene. On the other hand, in this sample, coarse-grained clinopyroxene shows an $\mathrm{X}_{\mathrm{Mg}}$ ratio and Ca content similar to clinopyroxene of websterite xenoliths contained in alkali basalts from Harrat Al Birk and Harrat Ash Shaam (Ghent et al. 1980; Shaw et al. 2007). On the basis of this evidence we can argue that coarsegrained clinopyroxene and enclosed orthopyroxene may represent millimetre-sized websterite xenoliths.

Post-magmatic alteration affects the dykes with different intensities. White mica replaces feldspars and it is associated with chlorite and epidote if it replaces plagioclase. In intermediate dykes AP-18, AP-19, and AP-20 alteration is widespread and much diffused. Phenocrysts are nearly completely replaced and locally their forming mineral phases are not recognizable. The groundmass is mostly affected by overgrowth of chlorite and epidote, which also forms granular aggregates. In rhyolitic samples (AP-16 and AP-17), K-feldspar is only affected by the overgrowth of very fine-grained magnetite. In basaltic/basanitic samples alteration is more diffused in sample AP-01 than in sample AP-08, which is quite pristine. In sample AP-01 coarse-grained plagioclase is replaced by abundant white mica, whereas finergrained plagioclase laths are pristine. Olivine is partially replaced by rims of talc and serpentine. In sample AP-08 talc and carbonate replaced millimetre-sized phenocrysts and domains in coarse-grained clinopyroxene. Since samples AP-01 and AP-08 have a similar composition (Figs. 14 and 15), talc and carbonates may represent the replacement of olivine. In sample AP-01 degassing bubbles are filled by mm-sized calcite and analcime, which contains minor K-feldspar, epidote, chlorite, and quartz. This mineral assemblage may result from late hydrothermal alteration (e.g., Rona et al. 1980). Also, degassing bubbles suggest that the final emplacement depth was as shallow as a few kilometres (e.g., Westrich et al. 1988; Aubry et al. 2013). Shallow levels of emplacement can be envisaged also for rhyolitic samples and sample AP-08 on the basis of the very fine-grained groundmass. The Al content 
in amphibole is correlated to pressure (Ridolfi and Renzulli 2012). On this basis, pressures of $0.39 \pm 0.13 \mathrm{GPa}$ and $0.55 \pm 0.02 \mathrm{GPa}$ are estimated for the crystallisation of amphibole in samples AP-01 and AP-08, respectively. Considering an average density for the continental crust of $2.83 \mathrm{~g} \mathrm{~cm}^{-3}$ (Christensen and Mooney 1995) depths of $14 \pm 5 \mathrm{~km}$ and $20 \pm 1 \mathrm{~km}$ are thus estimated for the crystallisation of amphibole in samples AP-01 and AP-08, respectively. In both cases these estimates do not represent the emplacement depth but only the crystallisation depth of amphibole, which may have carried toward the surface by the magma flow into the dyke as solid grains. According to the geothermobarometer of Ridolfi and Renzulli (2012), amphibole crystallised at temperatures of $842 \pm 58^{\circ} \mathrm{C}$ and $983 \pm 25^{\circ} \mathrm{C}$ in samples AP-01 and AP-08, respectively. According to the thermometer based on $\mathrm{X}_{\mathrm{Fe}}$ and $\mathrm{Al}$ content in chlorite (Cathelineau 1988; Jowett 1991), a temperature of $274 \pm 31^{\circ} \mathrm{C}$ can be estimated for the development of the alteration in andesitic samples AP-18 and A-19.

We started with U-Pb testing on samples containing zircon grains at least as large as $25 \mu \mathrm{m}$. These samples (AP-03, AP-05, and AP-14) consist of three granitoid dykes enclosing zircon grains that turned out to be Neoproterozoic in age. In particular, for sample AP-05, a late Cryogenian and early Ediacaran age of dyke emplacement can be tentatively proposed and ascribable to suturing events during the assemblage of the Arabian shield (see Fig. 2 and Table 9). Zircon grains from samples AP-03 and AP-14 have a strong inherited imprint, which most likely is related to the tectonic history predating the Arabian shield assemblage (see Fig. 2).

The mineral and geochemical composition reveals that the other seven dykes have a variable composition spanning from basanites to andesite and rhyolite (Fig. 14). On the ground of whole rock content in $\mathrm{Nb}$ and Th, samples AP-01 and AP-08 are compatible with extensional tectonics, whereas samples AP-18, AP-19, and AP-20 with convergent tectonics (see Fig. 15b and Table 9). Therefore, basanitic/basaltic samples AP-01 and AP-08 may be related to the Red Sea rifting and andesitic samples AP-18, AP-19, and AP-20 may be related to magmatism during the Pan-African orogeny. In support of this interpretation there are plenty of known Neoproterozoic mafic dykes in the Arabian shield, among which andesite and trachyandesite rocks occur (e.g., Kessel et al. 1998; Jarrar 2001), and that AP-18, AP-19, and AP-20 dykes were sampled about $50 \mathrm{~km}$ southeast from the Neoproterozoic Yanbu suture zone (Figs. 1 and 3). Indeed, andesitic magmas are generally common in subduction/collision contexts. Moreover, these three dykes are strongly altered and in the TAS diagram their 
composition is generally poorly comparable with the geochemical composition of magmatic rocks of Cenozoic harrats (Fig. 14). In contrast, the AP-01 and AP-08 dykes (especially AP08) are less altered than andesitic dykes and have a composition more similar to the Cenozoic magmatic rocks from Harrat Ash Shaam (Shaw et al. 2003) and central Syria (Krienitz et al. 2009) (see Fig. 14). Nevertheless, it should be noted that in the northern Arabian plate, late Neoproterozoic mafic dykes, which however show higher $\mathrm{SiO}_{2}$ and lower alkali content than samples AP-01 and AP-08, are interpreted as related to extensional tectonics (Kessel et al. 1998; Jarrar 2001). The two rhyolitic dykes in the TAS diagram (Fig. 14) show a composition very similar to part of the Ad Damm dyke suite in the central coastal plain of the Red Sea Arabian margin. As these dykes are ferroan rocks, most likely an origin in a convergent context (i.e., Pan-African orogeny) could be ruled out, since Cordilleran-type granitoid rocks usually show a marked magnesian signature (Frost et al. 2001 and references therein). Also, these dykes have been sampled in the region where rhyolitic dykes have been dated at around $20 \mathrm{Ma}$ (Pallister 1987) and their geochemical features can be typical of rhyolites emplaced during continental rifting or intraplate magmatism (Fig. 16). The rhyolitic dykes may have originated during partial melting of the continental crust due to the positive perturbation of thermal structure of the lithosphere during the Red Sea continental rifting. Alternatively, rhyolitic dykes may have been derived from differentiation of basaltic magma (see also discussions in Pallister 1987), as is also suggested by the ferroan chemical signature (Frost et al. 2001). In magma derived from the partial melting of the continental crust, minerals such as white mica or garnet usually testify to its peraluminous chemistry. Since the rhyolitic dykes do not contain such minerals, the second option might be more reliable. Finally, the strong morphological evidence of rhyolite (samples AP-16 and AP-17) and basaltic (sample AP-08) dykes (Fig. 5b, e, and f) is also consistent with these dykes being recent (Table 9).

\section{Acknowledgement}

This work was funded by the MIUR (Ministero dell'Istruzione, dell'Università e della Ricerca), PRIN (Progetti di Ricerca di Interesse Nazionale) protocol 20125JKANY "Rift-toDrift Transition in the Red Sea”. A. Schettino and P.P. Pierantoni carried out the fieldwork and sampled the dykes in 2015 with the financial support and logistic assistance of the Saudi Geological Survey. A. Schettino read the first draft of the chapter, A. Sanfilippo advised on whole rock geochemistry, and A. Rizzi assisted the work at the SEM. Four anonymous reviewers greatly helped with precious advices. 


\section{References}

Abdelsalam MG, Stern RJ (1996) Sutures and shear zones in the Arabian-Nubian Shield. J African Earth Sci 23:289-310. doi:10.1016/S0899-5362(97)00003-1

Al-Amri AM, Fnais MS, Abdel-Rahman K, Mogren S, Al-Dabbagh M (2012) Geochronological dating and stratigraphic sequences of Harrat Lunayyir, NW Saudi Arabia. Int J Phys Sci 7:2791-2805. doi:10.5897/IJPS12.178

Al-Husseini M (2015) Ediacaran-Cambrian Middle East geologic time scale 2015 spatiotemporal position of the Ediacaran Thalbah Basin in the Najd Fault System, Arabian Shield. GeoArabia 20:17-44

Ali KA, Azer MK, Gahlan HA, Wilde SA, Samuel MD, Stern RJ (2010) Age constraints on the formation and emplacement of Neoproterozoic ophiolites along the Allaqi-Heiani Suture, South Eastern Desert of Egypt. Gondwana Res 18:583-595. doi:10.1016/j.gr.2010.03.002

Almalki KA, Betts PG, Ailleres L (2014) Episodic sea-floor spreading in the southern Red Sea. Tectonophysics 617:140-149. doi:10.1016/j.tecto.2014.01.030

Al-Saleh AM, Boyle AP (2001) Structural rejuvenation of the eastern Arabian Shield during continental collision: ${ }^{40} \mathrm{Ar} /{ }^{39} \mathrm{Ar}$ evidence from the Ar Ridayniyah ophiolitic mélange. $\mathrm{J}$ African Earth Sci 33:135-141. doi:10.1016/S0899-5362(01)90094-6

ArRajehi A, McClusky S, Reilinger R, Daoud M, Alchalbi A, Ergintav S, Gomez F, Sholan J, Bou-Rabee F, Ogubazghi G, Haileab B, Fisseha S, Asfaw L, Mahmoud S, Rayan A, Bendik R, Kogan L (2010) Geodetic constraints on present-day motion of the Arabian Plate: Implications for Red Sea and Gulf of Aden rifting. Tectonics 29:TC3011. doi:10.1029/2009TC002482

Aubry GJ, Sator N, Guillot B (2013) Vesicularity, bubble formation and noble gas fractionation during MORB degassing. Chem Geol 343:85-98. doi:10.1016/j.chemgeo.2013.02.006

Audin L, Quidelleur X, Coulié E, Courtillot V, Gilder S, Manighetti I, Gillot P-Y, Tapponnier P, Kidane T (2004) Palaeomagnetism and K-Ar and ${ }^{40} \mathrm{Ar} /{ }^{39} \mathrm{Ar}$ ages in the Ali Sabieh area (Republic of Djibouti and Ethiopia): constraints on the mechanism of Aden ridge propagation into southeastern Afar during the last 10 Myr. Geophys J Int 158:327-345. doi:10.1111/j.1365-246X.2004.02286.x

Baker J, Snee L, Menzies M (1996) A brief Oligocene period of flood volcanism in Yemen: 
Implications for the duration and rate of continental flood volcanism at the Afro-Arabian triple junction. Earth Planet Sci Lett 138:39-55. doi:10.1016/0012-821X(95)00229-6

Bakhsh RA (2015) Pliocene-Quaternary basalts from the Harrat Tufail, western Saudi Arabia: Recycling of ancient oceanic slabs and generation of alkaline intra-plate magma. J African Earth Sci 112:37-54. doi:10.1016/j.jafrearsci.2015.08.010

Bayer H-J, El-Isa Z, Hotzl H, Mechie J, Prodehl C, Saffarini G (1989) Large tectonic and lithospheric structures of the Red Sea region. J African Earth Sci (and Middle East) 8:565-587. doi:10.1016/S0899-5362(89)80045-4

Be’eri-Shlevin Y, Eyal M, Eyal Y, Whitehouse MJ, Litvinovsky B (2012) The Sa'al volcanosedimentary complex (Sinai, Egypt): A latest Mesoproterozoic volcanic arc in the northern Arabian Nubian Shield. Geology 40:403-406. doi:10.1130/G32788.1

Be'eri-Shlevin Y, Katzir Y, Whitehouse M (2009) Post-collisional tectonomagmatic evolution in the northern Arabian-Nubian Shield: Time constraints from ion-probe U-Pb dating of zircon. J Geol Soc London 166:71-85. doi:10.1144/0016-76492007-169

Belachew M, Ebinger C, Cote D (2013) Source mechanisms of dike-induced earthquakes in the Dabbahu-Manda Hararo rift segment in Afar, Ethiopia: Implications for faulting above dikes. Geophys J Int 192:907-917. doi:10.1093/gji/ggs076

Bendick R, McClusky S, Bilham R, Asfaw L, Klemperer S (2006) Distributed Nubia-Somalia relative motion and dike intrusion in the Main Ethiopian Rift. Geophys J Int 165:303310. doi:10.1111/j.1365-246X.2006.02904.X

Bertrand H, Chazot G, Blichert-Toft J, Thoral S (2003) Implications of widespread high- $\mu$ volcanism on the Arabian Plate for Afar mantle plume and lithosphere composition. Chem Geol 198:47-61. doi:10.1016/S0009-2541(02)00418-7

Beyth M, Eyal Y, Garfunkel Z (2014) The geology of the northern tip of the Arabian-Nubian Shield. J African Earth Sci 99:332-341. doi:10.1016/j.jafrearsci.2014.03.028

Bicknell JD, MacDonald KC, Miller SP, Lonsdale PF, Becker K (1986) Tectonics of the Nereus Deep, Red Sea: A deep-tow investigation of a site of initial rifting. Mar Geophys Res 8:131-148. doi:10.1007/BF00338225

Bohannon RG, Naeser CW, Schmidt DL, Zimmermann RA (1989) The timing of uplift, volcanism, and rifting peripheral to the Red Sea: A case for passive rifting? J Geophys Res 94:1683-1701. doi:10.1029/JB094iB02p01683

Bonatti E (1985) Punctiform initiation of seafloor spreading in the Red Sea during transition from a continental to an oceanic rift. Nature 316:33-37. doi:10.1038/316033a0

Bonatti E, Colantoni P, Della Vedova B, Taviani M (1984) Geology of the Red Sea 
transitional region $\left(22^{\circ} \mathrm{N}-25^{\circ} \mathrm{N}\right)$. Oceanol Acta 7:385-398

Bosworth W, Huchon P, McClay K (2005) The Red Sea and Gulf of Aden Basins. J African Earth Sci 43:334-378

Bosworth W, Stockli DF (2016) Early magmatism in the greater Red Sea rift: Timing and significance. Can J Earth Sci 1-19. doi:10.1139/cjes-2016-0019

Buddington AF, Lindsley DH (1964) Iron-titanium oxide minerals and synthetic equivalents. J Petrol 5:310-357. doi:10.1093/petrology/5.2.310

Camp VE, Roobol MJ (1992) Upwelling asthenosphere beneath western Arabia and its regional implications. J Geophys Res 97:15255-15271. doi:10.1029/92JB00943

Cathelineau M (1988) Cation site occupancy in chlorites and illites as a function of temperature. Clay Miner 23:471-485

Chang S-J, Merino M, Van der Lee S, Stein S, Stein CA (2011) Mantle flow beneath Arabia offset from the opening Red Sea. Geophys Res Lett 38:L04301. doi:10.1029/2010GL045852

Chang S-J, Van der Lee S (2011) Mantle plumes and associated flow beneath Arabia and East Africa. Earth Planet Sci Lett 302:448-454. doi:10.1016/j.epsl.2010.12.050

Christensen NI, Mooney WD (1995) Seismic velocity structure and composition of the continental crust: A global view. J Geophys Res Solid Earth 100:9761-9788. doi:10.1029/95JB00259

Clark MD (1985) Late Proterozoic crustal evolution of the Midyan region, northwestern Saudi Arabia. Geology 13:611. doi:10.1130/0091-7613

Cochran JR (1981) The Gulf of Aden: Structure and evolution of a young ocean basin and continental margin. J Geophys Res 86:263. doi:10.1029/JB086iB01p00263

Cochran JR (1983) A model for development of Red Sea. Am Assoc Pet Geol Bull 67:41-69

Cochran JR, Martinez F, Steckler MS, Hobart MA (1986) Conrad deep: A new northern Red Sea deep. Earth Planet Sci Lett 78:18-32. doi:10.1016/0012-821X(86)90169-X

Coleman RG, Gregory RT, Brown GF (1983) Cenozoic volcanic rocks of Saudi Arabia. US Geol Surv Open File Rep USGS-OF-03-93, 82 pp. doi:10.3133/OFR83788

Coleman RG, McGuire AV (1988) Magma systems related to the Red Sea opening. Tectonophysics 150:77-100. doi:10.1016/0040-1951(88)90296-X

Coulié E, Quidelleur X, Gillot P-Y, Courtillot V, Lefèvre J-C, Chiesa S (2003) Comparative $\mathrm{K}-\mathrm{Ar}$ and $\mathrm{Ar} / \mathrm{Ar}$ dating of Ethiopian and Yemenite Oligocene volcanism: Implications for timing and duration of the Ethiopian traps. Earth Planet Sci Lett 206:477-492. doi:10.1016/S0012-821X(02)01089-0 
Courtillot V, Armijo R, Tapponnier P (1987) Kinematics of the Sinai triple junction and a two-phase model of Arabia-Africa rifting. Geol Soc London, Spec Publ 28:559-573. doi:10.1144/GSL.SP.1987.028.01.37

Daradich A, Mitrovica JX, Pysklywec RN, Willett SD, Forte AM (2003) Mantle flow, dynamic topography, and rift-flank uplift of Arabia. Geology 31:901-904. doi:10.1130/G19661.1

Davies FB (1985) Geological map of the Al Wahj Quadrangle, Sheet 26B, Kingdom of Saudi Arabia. Saudi Arabian Ministry of Petroleum and Mineral Resources, Directorate General of Mineral Resources

Davison I, Al-Kadasi M, Al-Khirbash S, Al-Subbary AK, Baker J, Blakey S, Bosence D, Dart C, Heaton R, McClay K, Menzies M, Nichols G, Owen L, Yelland A (1994) Geological evolution of the southeastern Red Sea Rift margin, Republic of Yemen. Geol Soc Am Bull 106:1474-1493. doi:10.1130/0016-7606

Desissa M, Johnson NE, Whaler KA, Hautot S, Fisseha S, Dawes GJK (2013) A mantle magma reservoir beneath an incipient mid-ocean ridge in Afar, Ethiopia. Nature Geosci 6:861-865. doi:10.1038/ngeo1925

Dilek Y, Ahmed Z (2003) Proterozoic ophiolites of the Arabian Shield and their significance in Precambrian tectonics. Geol Soc London, Spec Publ 218:685-700. doi:10.1144/GSL.SP.2003.218.01.33

Dixon TH, Stern RJ, Hussein IM (1987) Control of Red Sea rift geometry by Precambrian structures. Tectonics 6:551-571. doi:10.1029/TC006i005p00551

Droop GTR (1987) A general equation for estimating $\mathrm{Fe}^{3+}$ concentrations in ferromagnesian silicates and oxides from microprobe analyses, using stoichiometric criteria. Mineral Mag 51:431-435

Duncan RA, Al-Amri AM (2013) Timing and composition of volcanic activity at Harrat Lunayyir, western Saudi Arabia. J Volcanol Geotherm Res 260:103-116. doi:10.1016/j.jvolgeores.2013.05.006

Ebinger CJ, Ayele A, Keir D, Rowland J, Yirgu G, Wright T, Belachew M, Hamling I (2010) Length and timescales of rift faulting and magma intrusion: The Afar rifting cycle from 2005 to Present. Ann Rev Earth Planet Sci 38:439-466. doi:10.1146/annurev-earth040809-152333

Ebinger CJ, Keir D, Ayele A, Calais E, Wright TJ, Belachew M, Hammond JOS, Campbell E, Buck WR (2008) Capturing magma intrusion and faulting processes during continental rupture: Seismicity of the Dabbahu (Afar) rift. Geophys J Int 174:1138- 
1152. doi:10.1111/j.1365-246X.2008.03877.x

Eby GN (1992) Chemical subdivision of the A-type granitoids: Petrogenetic and tectonic implications. Geology 20:661-664

Ehrhardt A, Hübscher C, Gajewski D (2005) Conrad Deep, northern Red Sea: Development of an early stage ocean deep within the axial depression. Tectonophysics 411:19-40. doi:10.1016/j.tecto.2005.08.011

El-Bialy MZ, Omar MM (2015) Spatial association of Neoproterozoic continental arc I-type and post-collision A-type granitoids in the Arabian-Nubian Shield: The Wadi AlBaroud Older and Younger Granites, North Eastern Desert, Egypt. J African Earth Sci 103:1-29. doi:10.1016/j.jafrearsci.2014.11.013

Farahat ES, Mohamed HA, Ahmed AF, El Mahallawi MM (2007) Origin of I- and A-type granitoids from the Eastern Desert of Egypt: Implications for crustal growth in the northern Arabian-Nubian Shield. J African Earth Sci 49:43-58. doi:10.1016/j.jafrearsci.2007.07.002

Fournier M, Chamot-Rooke N, Petit C, Huchon P, Al-Kathiri A, Audin L, Beslier M-O, d'Acremont E, Fabbri O, Fleury J-M, Khanbari K, Lepvrier C, Leroy S, Maillot B, Merkouriev S (2010) Arabia-Somalia plate kinematics, evolution of the Aden-OwenCarlsberg triple junction, and opening of the Gulf of Aden. J Geophys Res 115:B04102. doi:10.1029/2008JB006257

Fritz H, Abdelsalam M, Ali KA, Bingen B, Collins AS, Fowler AR, Ghebreab W, Hauzenberger CA, Johnson PR, Kusky TM, Macey P, Muhongo S, Stern RJ, Viola G (2013) Orogen styles in the East African Orogen: A review of the Neoproterozoic to Cambrian tectonic evolution. J African Earth Sci 86:65-106. doi:10.1016/j.jafrearsci.2013.06.004

Frost BR, Barnes CG, Collins WJ, Arculus RJ, Ellis DJ, Frost CD (2001) A geochemical classification for granitic rocks. J Petrol 42:2033-2048. doi:10.1093/petrology/42.11.2033

Garson MS, Krs M (1976) Geophysical and geological evidence of the relationship of Red Sea transverse tectonics to ancient fractures. Geol Soc Am Bull 87:169-181. doi:10.1130/0016-7606

Gaulier JM, Le Pichon X, Lyberis N, Avedik F, Geli L, Moretti I, Deschamps A, Hafez S (1988) Seismic study of the crust of the northern Red Sea and Gulf of Suez. Tectonophysics 153:55-88. doi:10.1016/0040-1951(88)90007-8

Genna A, Nehlig P, Le Goff E, Guerrot C, Shanti M (2002) Proterozoic tectonism of the 
Arabian Shield. Precambrian Res 117:21-40

Ghebreab W (1998) Tectonics of the Red Sea region reassessed. Earth-Sci Rev 45:1-44. doi:10.1016/S0012-8252(98)00036-1

Ghebreab W, Talbot CJ (2000) Red Sea extension influenced by Pan-African tectonic grain in eastern Eritrea. J Struct Geol 22:931-946. doi:10.1016/S0191-8141(00)00022-5

Ghent ED, Coleman RG, Hadley DG (1980) Ultramafic inclusions and host alkali olivine basalts of the southern coastal plain of the Red Sea, Saudi Arabia. Am J Sci 280-A:499527

Gosso G, Rebay G, Roda M, Spalla MI, Tarallo M, Zanoni D, Zucali M (2015) Taking advantage of petrostructural heterogeneities in subduction-collisional orogens, and effect on the scale of analysis. Period. Mineral. (2015), 84(3B), 779-825. doi:10.2451/ 2015PM0452

Grainger DJ, Hanif R (1989) Geologic map of the Shaghab Quadrangle, Sheet 27 B, Kingdom of Saudi Arabia. Saudi Arabian Ministry of Petroleum and Mineral Resources, Directorate General of Mineral Resources

Green NL, Usdansky SI (1986) Toward a practical plagioclase-muscovite thermometer. Am Mineral 71:1109-1117

Hansen SE, Rodgers AJ, Schwartz SY, Al-Amri AMS (2007) Imaging ruptured lithosphere beneath the Red Sea and Arabian Peninsula. Earth Planet Sci Lett 259:256-265. doi:10.1016/j.epsl.2007.04.035

Hargrove US, Stern RJ, Kimura J-I, Manton WI, Johnson PR (2006) How juvenile is the Arabian-Nubian Shield? Evidence from Nd isotopes and pre-Neoproterozoic inherited zircon in the Bi'r Umq suture zone, Saudi Arabia. Earth Planet Sci Lett 252:308-326. doi:10.1016/j.epsl.2006.10.002

Hempton MR (1987) Constraints on Arabian Plate motion and extensional history of the Red Sea. Tectonics 6:687-705. doi:10.1029/TC006i006p00687

Hey MH (1954) A new review of the chlorites. Mineral Mag 30:277-292

Hiess J, Condon DJ, McLean N, Noble SR (2012) 238U/235U systematics in terrestrial uranium-bearing minerals. Geology 335:1610-1614. doi:10.1126/science.1215507

Hofmann C, Courtillot V, Féraud G, Rochette P, Yirgu G, Ketefo E, Pik R (1997) Timing of the Ethiopian flood basalt event and implications for plume birth and global change. Nature 389:838-841. doi:10.1038/39853

Horstwood MSA, Foster GL, Parrish RR, Noble SR, Nowell GM (2003) Common-Pb corrected in situ U-Pb accessory mineral geochronology by LA-MC-ICP-MS. J Anal At 
Spectrom 18:837-846. doi:10.1039/B304365G

Ibrahim KM, Al-Malabeh A (2006) Geochemistry and volcanic features of Harrat El Fahda:

A young volcanic field in northwest Arabia, Jordan. J Asian Earth Sci 27:147-154. doi:10.1016/j.jseaes.2005.01.009

Ibrahim KM, McCourt WJ (1995) Neoproterozoic granitic magmatism and tectonic evolution of the northern Arabian Shield: Evidence from southwest Jordan. J African Earth Sci 20:103-118. doi:10.1016/0899-5362(95)00037-T

Ibrahim KM, Tarawneh K, Rabba’ I (2003) Phases of activity and geochemistry of basaltic dike systems in northeast Jordan parallel to the Red Sea. J Asian Earth Sci 21:467-472. doi:10.1016/S1367-9120(02)00075-5

Ilani S, Harlavan Y, Tarawneh K, Rabba I, Weinberger R, Ibrahim K, Peltz S, Steinitz G (2001) New K-Ar ages of basalts from the Harrat Ash Shaam volcanic field in Jordan: Implications for the span and duration of the upper-mantle upwelling beneath the western Arabian plate. Geology 29:171-174. doi:10.1130/0091-7613

Irvine TN, Baragar WRA (1971) A guide to the chemical classification of the common volcanic rocks. Can J Earth Sci 8:523-548. doi:10.1139/e71-055

Jackson SE, Pearson NJ, Griffin WL, Belousova EA (2004) The application of laser ablationinductively coupled plasma-mass spectrometry to in situ U-Pb zircon geochronology. Chem Geol 211:47-69. doi:10.1016/j.chemgeo.2004.06.017

Jarrar G (2001) The youngest Neoproterozoic mafic dyke suite in the Arabian Shield: Mildly alkaline dolerites from South Jordan - their geochemistry and petrogenesis. Geol Mag 138:309-323. doi:10.1017/S0016756801005295

Johnson PR (1998) Tectonic map of Saudi Arabia and adjacent areas. Saudi Arabian Ministry of Petroleum and Mineral Resources, Deputy Ministry for Mineral Resources Technical Report USGS-TR-98-3 (IR 948)

Johnson PR, Andresen A, Collins AS, Fowler AR, Fritz H, Ghebreab W, Kusky T, Stern RJ (2011) Late Cryogenian-Ediacaran history of the Arabian-Nubian Shield: A review of depositional, plutonic, structural, and tectonic events in the closing stages of the northern East African Orogen. J African Earth Sci 61:167-232. doi:10.1016/j.jafrearsci.2011.07.003

Johnson PR, Kattan FH, Al-Saleh AM (2004) Neoproterozoic ophiolites in the Arabian Shield: Field relations and structure. Dev Precambrian Geol 13:129-162. doi:10.1016/S0166-2635(04)13004-1

Jowett EC (1991) Fitting iron and magnesium into the hydrothermal chlorite 
geothermometer. In: Geological Association of Canada/Mineralogical Association of Canada/Society of Economic Geologists Joint Annual Meeting, abstracts, p 62

Kaliwoda M, Altherr R, Meyer H-P (2007) Composition and thermal evolution of the lithospheric mantle beneath the Harrat Uwayrid, eastern flank of the Red Sea rift (Saudi Arabia). Lithos 99:105-120. doi:10.1016/j.lithos.2007.06.013

Keir D, Ebinger CJ, Stuart GW, Daly E, Ayele A (2006) Strain accommodation by magmatism and faulting as rifting proceeds to breakup: Seismicity of the northern Ethiopian rift. J Geophys Res Solid Earth 111:B05314. doi:10.1029/2005JB003748

Kessel R, Stein M, Navon O (1998) Petrogenesis of late Neoproterozoic dikes in the northern Arabian-Nubian Shield: Implications for the origin of A-type granites. Precambrian Res 92:195-213. doi:10.1016/S0301-9268(98)00075-8

Ketchum JWF, Jackson SE, Culshaw NG, Barr SM (2001) Depositional and tectonic setting of the Paleoproterozoic Lower Aillik Group, Makkovik Province, Canada: Evolution of a passive margin-foredeep sequence based on petrochemistry and U-Pb (TIMS and LAM-ICP-MS) geochronology. Precambrian Res 105:331-356. doi:10.1016/S03019268(00)00118-2

Khattab MM (1992) The extent of oceanization of the Egyptian northern Red Sea crust indicated by gravity and magnetic data. J African Earth Sci (and Middle East) 14:493498. doi:10.1016/0899-5362(92)90081-M

Koulakov I, El Khrepy S, Al-Arifi N, Sychev I, Kuznetsov P (2014) Evidence of magma activation beneath the Lunayyir basaltic field (Saudi Arabia) from attenuation tomography. Solid Earth Discuss 6:1401-1421. doi:10.5194/sed-6-1401-2014

Krienitz M-S, Haase KM, Mezger K, van den Bogaard P, Thiemann V, Shaikh-Mashail MA (2009) Tectonic events, continental intraplate volcanism, and mantle plume activity in northern Arabia: Constraints from geochemistry and Ar-Ar dating of Syrian lavas. Geochem Geophys Geosyst 10. doi:10.1029/2008GC002254

Kröner A (1985) Ophiolites and the evolution of tectonic boundaries in the late proterozoic Arabian-Nubian shield of northeast Africa and Arabia. Precambrian Res 27:277-300. doi:10.1016/0301-9268(85)90016-6

Kröner A, Linnebacher P, Stern RJ, Reischmann T, Manton W, Hussein IM (1991) Evolution of Pan-African island arc assemblages in the southern Red Sea Hills, Sudan, and in southwestern Arabia as exemplified by geochemistry and geochronology. Precambrian Res 53:99-118. doi:10.1016/0301-9268(91)90007-W

Lazar M, Ben-Avraham Z, Garfunkel Z (2012) The Red Sea - new insights from recent 
geophysical studies and the connection to the Dead Sea fault. J African Earth Sci 68:96110. doi:10.1016/j.jafrearsci.2012.04.001

Leake BE, Woolley AR, Arps CES, Birch WD, Gilbert MC, Grice JD, Hawthorne FC, Kato A, Kisch HJ, Krivovichev VG, Linthout K, Laird J, Mandarino JA, Maresch W V, Nickel EH, Rock NMS, Schumacher JC, Smith DC, Stephenson NCN, Ungaretti L, Whittaker EJW, Guo Y (1997) Nomenclature of amphiboles; Report of the Subcommittee on Amphiboles of the International Mineralogical Association, Commission on New Minerals and Mineral Names. Am Mineral 82:1019-1037

Locock AJ (2014) An Excel spreadsheet to classify chemical analyses of amphiboles following the IMA 2012 recommendations. Comput Geosci 62:1-11. doi:10.1016/j.cageo.2013.09.011

Ludwig KR (2003) Isoplot/Ex version 3.0: A geochronological toolkit for Microsoft Excel. In: Berkeley Geochronology Center Special Publication 4. Berkeley Geochronology Center, Berkeley, 70 pp

Makris J, Rihm R (1991) Shear-controlled evolution of the Red Sea: Pull apart model. Tectonophysics 198:441-466. doi:10.1016/0040-1951(91)90166-P

Manetti P, Capaldi G, Chiesa S, Civetta L, Conticelli S, Gasparon M, La Volpe L, Orsi G (1991) Magmatism of the eastern Red Sea margin in the northern part of Yemen from Oligocene to present. Tectonophysics 198:181-202. doi:10.1016/0040-1951(91)90150Q

Mohr P (1983) Ethiopian flood basalt province. Nature 303:577-584. doi:10.1038/303577a0 Morimoto N (1988) Nomenclature of pyroxenes. Mineral Mag 52:535-550

Moufti MR, Moghazi AM, Ali KA (2013) ${ }^{40} \mathrm{Ar} /{ }^{39} \mathrm{Ar}$ geochronology of the NeogeneQuaternary Harrat Al-Madinah intercontinental volcanic field, Saudi Arabia: Implications for duration and migration of volcanic activity. J Asian Earth Sci 62:253268. doi:10.1016/j.jseaes.2012.09.027

Nehlig P, Asfirane F, Genna A, Guerrot C, Nicol N, Salpeteur I, Shanti M, Thiéblemont D (2001) Aeromagnetic map constrains cratonization of the Arabian Shield. Terra Nov 13:347-353. doi:10.1046/j.1365-3121.2001.00370.x

Nehlig P, Genna A, Asfirane F, Dubreuil N, Guerrot C, Eberlé JM, Kluyver HM, Lasserre JM, Le Goff E, Nicol N, Salpeteur N, Shanti M, Thiéblemont D, Truffert C (2002) A review of the Pan-African evolution of the Arabian Shield. GeoArabia 7:103-124 Pallister JS (1987) Magmatic history of Red Sea rifting: Perspective from the central Saudi Arabian coastal plain. Geol Soc Am Bull 98:400-417. doi:10.1130/0016-7606 
Pallister JS (1986) Geologic map of the Al Lith Quadrangle, Sheet 20D, Kingdom of Saudi Arabia. Ministry of Petroleum and Mineral Resources, Directorate General of Mineral Resources

Pallister JS, McCausland WA, Jónsson S, Lu Z, Zahran HM, El Hadidy S, Aburukbah A, Stewart ICF, Lundgren PR, White RA, Moufti MRH (2010) Broad accommodation of rift-related extension recorded by dyke intrusion in Saudi Arabia. Nat Geosci 3:705712. doi:10.1038/ngeo966

Pallister JS, Stacey JS, Fischer LB, Premo WR (1987) Arabian Shield ophiolites and Late Proterozoic microplate accretion. Geology 15:320. doi:10.1130/0091-7613

Park Y, Nyblade AA, Rodgers AJ, Al-Amri A (2007) Upper mantle structure beneath the Arabian Peninsula and northern Red Sea from teleseismic body wave tomography: Implications for the origin of Cenozoic uplift and volcanism in the Arabian Shield. Geochem Geophys Geosyst 8:Q06021. doi:10.1029/2006GC001566

Passchier CW, Trouw RAJ (2005) Microtectonics. Springer, Berlin, Heidelberg, New York Paterson SR, Vernon RH, Tobisch OT (1989) A review of criteria for the identification of magmatic and tectonic foliation in granitoids. J Struct Geol 11:349-363

Pautot G (1983) Les fosses de la Mer Rouge: Approche géomorphologique d'un stade initial d'ouverture océanique réalisée à l'aide du Seabeam. Oceanol Acta 6:235-244

Pavoni N (1992) Rifting of Africa and pattern of mantle convection beneath the African plate. Tectonophysics 215:35-53. doi:10.1016/0040-1951(92)90073-F

Pellaton C (1982) Geological map of the Umm Laji Quadrangle, Sheet 25 B, Kingdom of Saudi Arabia. Saudi Arabian Ministry of Petroleum and Mineral Resources, Directorate General of Mineral Resources

Pellaton C (1979) Geological map the Yanbu al Bahr Quadrangle, Sheet 24C, Kingdom of Saudi Arabia. Saudi Arabian Ministry of Petroleum and Mineral Resources, Directorate General of Mineral Resources

Pryer LL, Robin P-YF (1996) Differential stress control on the growth and orientation of flame perthite: A palaeostress direction indicator. J Struct Geol 18:1151-1166

Quick JE (1991) Late Proterozoic transpression on the Nabitah fault system - implications for the assembly of the Arabian Shield. Precambrian Res 53:119-147. doi:10.1016/03019268(91)90008-X

Ridolfi F, Renzulli A (2012) Calcic amphiboles in calc-alkaline and alkaline magmas: Thermobarometric and chemometric empirical equations valid up to $1,130^{\circ} \mathrm{C}$ and 2.2 GPa. Contrib Mineral Petrol 163:877-895. doi:10.1007/s00410-011-0704-6 
Riisager P, Knight KB, Baker JA, Ukstins Peate I, Al-Kadasi M, Al-Subbary A, Renne PR (2005) Paleomagnetism and ${ }^{40} \mathrm{Ar} /{ }^{39} \mathrm{Ar}$ Geochronology of Yemeni Oligocene volcanics: Implications for timing and duration of Afro-Arabian traps and geometry of the Oligocene paleomagnetic field. Earth Planet Sci Lett 237:647-672. doi:10.1016/j.epsl.2005.06.016

Robinson FA, Foden JD, Collins AS, Payne JL (2014) Arabian Shield magmatic cycles and their relationship with Gondwana assembly: Insights from zircon $\mathrm{U}-\mathrm{Pb}$ and $\mathrm{Hf}$ isotopes. Earth Planet Sci Lett 408:207-225. doi:10.1016/j.epsl.2014.10.010

Roger J, Platel JP, Cavelier C, Bourdillon-de-Grissac C (1989) Données nouvelles sur la stratigraphie et l'histoire géologique du Dhofar (sultanat d'Oman). Bull Société Géologique Fr 8:265-277. doi:10.2113/gssgfbull.v.2.265

Rollinson H (1993) Using geochemical data: Evaluation, presentation, interpretation. Longman, Essex

Rona PA, Boström K, Epstein S (1980) Hydrothermal quartz vug from the Mid-Atlantic Ridge. Geology 8:569-572. doi:10.1130/0091-7613

Roobol MJ, Al-Rehaili M (1998) Geohazards along the Makkah-Madinah-Nafud (MMN) volcanic line. Saudi Arabian Deputy Ministry for Mineral Resources Tech Rep BRGMTR-98, 20 pp

Rooney TO, Hanan BB, Graham DW, Furman T, Blichert-Toft J, Schilling J-G (2012) Upper mantle pollution during Afar plume-continental rift interaction. J Petrol 53:365-389. doi:10.1093/petrology/egr065

Runge MG, Bebbington MS, Cronin SJ, Lindsay JM, Moufti MR (2016) Integrating geological and geophysical data to improve probabilistic hazard forecasting of Arabian Shield volcanism. J Volcanol Geotherm Res 311:41-59. doi:10.1016/j.jvolgeores.2016.01.007

Saccani E (2015) A new method of discriminating different types of post-Archean ophiolitic basalts and their tectonic significance using Th-Nb and Ce-Dy-Yb systematics. Geosci Front 6:481-501. doi:10.1016/j.gsf.2014.03.006

Schettino A, Macchiavelli C, Pierantoni PP, Zanoni D, Rasul N (2016) Recent kinematics of the tectonic plates surrounding the Red Sea and Gulf of Aden. Geophys J Int 207:457480. doi:10.1093/gji/ggw280

Schmidt DL, Hadley DG, Brown GF (1983) Middle Tertiary continental rift and evolution of the Red Sea in southwestern Saudi Arabia. Saudi Arabian Deputy Ministry for Mineral Resources, Open-File Report, USGS-OF-03-06, 56 pp 
Sebai A, Zumbo V, Féraud G, Bertrand H, Hussain AG, Giannérini G, Campredon R (1991) $40 \mathrm{Ar} / 39 \mathrm{Ar}$ dating of alkaline and tholeiitic magmatism of Saudi Arabia related to the early Red Sea Rifting. Earth Planet Sci Lett 104:473-487. doi:10.1016/0012821X(91)90223-5

Shanti M, Roobol MJ (1979) A late Proterozoic ophiolite complex at Jabal Ess in northern Saudi Arabia. Nature 279:488-491. doi:10.1038/279488a0

Shaw JE, Baker JA, Kent AJR, Ibrahim KM, Menzies MA (2007) The geochemistry of the Arabian lithospheric mantle - a source for intraplate volcanism? J Petrol 48:1495-1512. doi:10.1093/petrology/egm027

Shaw JE, Baker JA, Menzies MA, Thirwall MF, Ibrahim KM (2003) Petrogenesis of the largest intraplate volcanic field on the Arabian plate (Jordan): A mixed lithosphereasthenosphere source activated by lithospheric extension. J Petrol 44:1657-1679. doi:10.1093/petrology/egg052

Stern RJ (1994) Neoproterozoic (900-550 Ma) arc assembly and continental collision in the East African orogen: Implications for the consolidation of Gondwanaland. Ann Rev Earth Planet Sci 22:319-351

Stern RJ, Gottfried D, Hedge CE (1984) Late Precambrian rifting and crustal evolution in the northeastern desert of Egypt. Geology 12:168. doi:10.1130/0091-7613

Stipp M, Stünitz H, Heilbronner R, Schmid SM (2002) The eastern Tonale fault zone: A “natural laboratory” for crystal plastic deformation of quartz over a temperature range from 250 to $700^{\circ}$ C. J Struct Geol 24:1861-1884. doi:10.1016/S0191-8141(02)00035-4

Stoeser DB, Camp VE (1985) Pan-African microplate accretion of the Arabian Shield. Geol Soc Am Bull 96:817-826. doi:10.1130/0016-7606

Stoeser DB, Frost CD (2006) Nd, Pb, Sr, and O isotopic characterization of Saudi Arabian Shield terranes. Chem Geol 226:163-188. doi:10.1016/j.chemgeo.2005.09.019

Stoeser DB, Whitehouse MJ, Stacey JS (2001) The Khida terrane? Geology of Paleoproterozoic rocks in the Muhayil area, eastern Arabian shield, Saudi Arabia. Gondwana Res 4:192-194. doi:10.1016/S1342-937X(05)70691-2

Sultan M, Becker R, Arvidson RE, Shore P, Stern RJ, El Alfy Z, Attia RI (1993) New constraints on Red Sea rifting from correlations of Arabian and Nubian Neoproterozoic outcrops. Tectonics 12:1303-1319. doi:10.1029/93TC00819

Sun S-s, McDonough WF (1989) Chemical and isotopic systematics of oceanic basalts: Implications for mantle composition and processes. Geol Soc London, Spec Publ 42:313-345. doi:10.1144/GSL.SP.1989.042.01.19 
Vail JR (1985) Pan-African (late Precambrian) tectonic terrains and the reconstruction of the Arabian-Nubian Shield. Geology 13:839-842. doi:10.1130/0091-7613

Van Achterbergh E, Ryan CG, Jackson SE, Griffin WL (2001) Data reduction software for LAICPMS. In: Sylvester P (ed) Laser ablation ICPMS in the earth sciences: Principles and applications. Mineralogical Association of Canada Short Course Ser 29, pp 239-243

Veeningen R, Rice AHN, Schneider DA, Grasemann B (2015) Thermochronology and geochemistry of the Pan-African basement below the Sab’atayn Basin, Yemen. J African Earth Sci 102:131-148. doi:10.1016/j.jafrearsci.2014.11.009

Vernon RH (2004) A practical guide to rock microstructure. Cambridge University Press

Westrich HR, Stockman HW, Eichelberger JC (1988) Degassing of rhyolitic magma during ascent and emplacement. J Geophys Res 93:6503. doi:10.1029/JB093iB06p06503

Wilson JWP, Roberts GG, Hoggard MJ, White NJ (2014) Cenozoic epeirogeny of the Arabian Peninsula from drainage modeling. Geochem Geophys Geosyst 15:3723-3761. doi:10.1002/2014GC005283

Winchester JA, Floyd PA (1977) Geochemical discrimination of different magma series and their differentiation products using immobile elements. Chem Geol 20:325-343. doi:10.1016/0009-2541(77)90057-2

Windley BF, Whitehouse MJ, Ba-Bttat MAO (1996) Early Precambrian gneiss terranes and Pan-African island arcs in Yemen: Crustal accretion of the eastern Arabian Shield. Geology 24:131. doi:10.1130/0091-7613

Wright TJ, Ebinger C, Biggs J, Ayele A, Yirgu G, Keir D, Stork A (2006) Magmamaintained rift segmentation at continental rupture in the 2005 Afar dyking episode. Nature 442:291-294. doi:10.1038/nature04978

\section{Figure captions}

Figure 1. Tectonic sketch map of the Arabian shield showing the Neoproterozoic terranes, the major suture belts and fault zones (Johnson 1998), and the Cenozoic harrats or volcanic fields (grey). The Neoproterozoic structures reactivated during the Red Sea rifting are highlighted in red. Plate boundaries, rift axes, and velocity vectors at plate boundaries are from Schettino et al. (2016). 
Figure 2: Summary of the tectonic and magmatic events recorded in the Arabian shield, modified after Genna et al. (2002) and Fritz et al. (2013). Red = post-orogenic magmatism; green = oceanic magmatism, pale blue = arc magmatism. Time scale in Ma (million years).

Figure 3: Location map of studied dykes, showing present-day plate boundaries and transverse structures around the Red Sea (after Schettino et al. 2016). White shaded polygons: Cenozoic volcanic harrats redrawn after Coleman et al. (1983) and Roobol and AlRehaili (1998). White (not dated) and red (dated) segments indicate the strike of the studied dykes (not to scale).

Figure 4: Age compilation of Cenozoic volcanic harrats in the Arabian shield. Black from Camp and Roobol (1992) and red from Runge et al. (2016) compilations, respectively.

Figure 5: a) Granitoid rocks intruded by basaltic dyke. AP-01 was sampled from this dyke. A. Schettino for scale; b) metre-thick basaltic dyke intruded in granitoid rocks. The dyke is responsible for shaping the hill that dominates the middle of the wadi. AP-08 was sampled from this dyke; c) decimetre-thick basaltic dyke intruded in granitoid rocks. AP-19 was sampled from this dyke. P.P. Pierantoni for scale; d) 1 metre-thick basaltic dyke intruded in granitoid rocks. AP-20 was sampled from this dyke; e) metre-thick rhyolitic dyke intruded in metavolcanic rocks. AP-16 was sampled from this dyke; f) metre-thick rhyolitic dyke intruded in metavolcanic rocks. Clearly the dyke is responsible for shaping the ridge over a kilometric distance. AP-17 was sampled from this dyke.

Figure 6: a) Tartan twinning in microcline (Kfs) (sample AP-05); crossed polars; b) graphic intergrowth between microcline (Kfs) and quartz (Qz) (sample AP-05). Quartz shows subrounded faces against K-feldspar that suggest recrystallization; c) very altered K-feldspar (Kfs) phenocryst that encloses fine-grained euhedral plagioclase (Pl) (sample AP-03); crossed polars; d) plagioclase (Pl) rim free of replacing mineral phases such as white mica, chlorite, and epidote (sample AP-14). Note that locally epidote in the replacing aggregate is in wellformed crystals; crossed polars; e) rounded quartz (Qz) crystals surrounded by interstitial Kfeldspar (Kfs), close to a K-feldspar phenocryst (sample AP-03). K-feldspar is completely altered by very fine-grained aggregate mostly consisting of white mica. Plane polarised light; f) massive aggregate of green hornblende ( $\mathrm{Hbl})$ and minor biotite $(\mathrm{Bt})$ (sample AP-14). Plane polarised light. 
Figure 7: a) Euhedral plagioclase phenocryst that contains glass (yellowish patches) in the core and in the rim (sample AP-08). Phenocryst contains also rounded orthopyroxene (Opx); plane polarized light; b) plagioclase (Pl) phenocrysts widely overgrown by white mica (Wm) (sample AP-01). Euhedral to sub-euhedral brown amphibole (Amp) grains are surrounded by the rock matrix; crossed polars; c) brown amphibole (Amp) phenocrysts with a thick rim of opaque minerals (sample AP-08). Amphibole, plagioclase (Pl), and clinopyroxene (Cpx) show shape-preferred orientation defining the fluidal structure; plane polarized light; d) euhedral plagioclase (Pl) laths and subhedral clinopyroxene (Cpx) (sample AP-01); plagioclase also forms interstitial grains; plane polarized light; e) very coarse-grained clinopyroxene (Cpx) surrounded by the groundmass in which shape preferred orientation of fine-grained plagioclase defines a fluidal structure (sample AP-08). Finer-grained orthopyroxene (Opx) crystals occur at margins of and are contained in clinopyroxene; crossed polars (photo merging of photomicrographs which results into an apparent plane within clinopyroxene); f) rounded analcime crystals enclosing K-feldspar and epidote (sample AP01); plane polarized light.

Figure 8: a) Relict amphibole (Amp) phenocryst that is completely replaced mainly by actinolite (sample AP-18). The original magmatic minerals in the rock matrix are hardly recognizable; crossed polars; b) close up of Fig. 8a; in the rock matrix plagioclase (ex-Pl) laths widely replaced by white mica (Wm) are recognizable as well as fine grained amphibole; quartz (Qz) forms pristine interstitial grains; crossed polars; c) relict amphibole (Amp) in the rock matrix replaced by actinolite (Act) and chlorite (Chl) (sample AP-18); Kfeldspar (Kfs) marks the boundaries between plagioclase and quartz; backscattered electron image; d) pristine clinopyroxene (Cpx) phenocryst intersected by chlorite-bearing fractures; crossed polars.

Figure 9: a) Aggregate of K-feldspar phenocrysts (mottled) with interstitial quartz (white patches) (sample AP-17); quartz is very diffused in the ground mass; plane polarized light; b) euhedral K-feldspar (Kfs) phenocryst with perthitic albite (Ab) (sample AP-16); magnetite (Mag) forms very-fine grained crystal aggregates on K-feldspar phenocrysts and subhedral to euhedral crystals in the groundmass; backscattered electron image. 
Figure 10: Backscattered electron images of zircon grains; a) zircon grain in a groundmass of albite (Ab) and chlorite (Chl) (sample AP-03); b) close-up of the zircon grain that shows zoning features (sample AP-03); c) zircon grain with zoning features (sample AP-05); d) zircon grains containing quartz-inclusions (sample AP-14); e) euhedral zircon grain surrounded by quartz $(\mathrm{Qz})$ and plagioclase $(\mathrm{Pl})$ crystals, with minor biotite $(\mathrm{Bt}=$ small white grains) (sample AP-14); f) close-up of the image "e” showing zoning features in zircon grain.

Figure 11: Distribution diagram of U-Pb concordant age data for samples AP-03, AP-05, and AP-14.

Figure 12: a) Binary diagram for amphibole showing $\mathrm{Na} /(\mathrm{Na}+\mathrm{Ca})$ versus $\mathrm{Al} /(\mathrm{Al}+\mathrm{Si})$. Black stars locate the end-member compositions according to Leake et al. (1997): Act = actinolite, Ts = tschermakite, Sad = sadanagaite, Prg = pargasite, Bar = barroisite, $\mathrm{Ktp}=$ katophorite, $\mathrm{Gl}$ = glaucophane, Win = winchite, $\mathrm{Ed}$ = edenite; b) binary diagram showing the variation of $\mathrm{Ti}$ versus $\mathrm{Al}$ in amphibole; c) classification ternary diagram Wo (wollastonite) versus En (enstatite) versus Fs (ferrosilite) in pyroxene (Morimoto 1988); d) binary diagram showing the variation of $\mathrm{Ca}$ versus $\mathrm{Mg} / \mathrm{Mg}+\mathrm{Fe}^{2+}$ in pyroxene; e) classification ternary diagram of feldspar; $\mathrm{An}=$ anorthite, $\mathrm{Ab}=$ albite, $\mathrm{Or}=$ orthoclase.

Figure 13: a) ternary diagram showing the variation of $\mathrm{X}_{\mathrm{Al}}\left(\mathrm{Al} /\left(\mathrm{Al}+\mathrm{Cr}+\mathrm{Fe}^{3+}\right)\right)$ versus $\mathrm{X}_{\mathrm{Cr}}$ $\left(\mathrm{Cr} /\left(\mathrm{Al}+\mathrm{Cr}+\mathrm{Fe}^{3+}\right)\right)$ versus $\mathrm{X}_{\mathrm{Fe}}{ }^{3+}\left(\mathrm{Fe}^{3+} /\left(\mathrm{Al}+\mathrm{Cr}+\mathrm{Fe}^{3+}\right)\right)$ in spinel; b) classification ternary diagram for spinel that shows the variation of $\mathrm{Fe}_{2} \mathrm{O}_{3}$ versus $\mathrm{FeO}$ versus $\mathrm{TiO}_{2}$ (Buddington and Lindsley 1964); c) classification binary diagram for chlorite (Hey 1954); d) ternary diagram showing the variation of $\mathrm{Al}$ versus $\mathrm{Fe}^{3+}$ versus $\mathrm{Ca}$ in epidote; e) ternary diagram showing the variation of $\mathrm{Al}$ versus $\mathrm{Fe}+\mathrm{Mg}$ versus $\mathrm{Si}$ in white mica; $\mathbf{f}) \mathrm{X}_{\mathrm{Pg}}$ (molar fraction of paragonite) versus $\mathrm{X}_{\mathrm{Ms}}$ (molar fraction of muscovite) binary diagram; $\mathrm{X}_{\mathrm{Ms}}$ is according to Green and Usdansky (1986).

Figure 14: TAS (total alkali versus silica) classification diagram. In red data analysed in this chapter are indicated and are compared with the composition of Cenozoic magmatic rocks in the Arabian plate from: Al Lith area in open circles (Pallister 1987), Harrat as Sirat, Harrat Khaybar, and Harrat al Birk in open diamonds (Coleman et al. 1983), Harrat Lunayyir in grey shading (Duncan and Al-Amri 2013), Harrat Al Birk in open squares (Ghent et al. 1980), Harrat Ash Shaam, northeast Jordan in blue dotted line (Ibrahim et al. 2003; Shaw et al. 
2003; Ibrahim and Al-Malabeh 2006), Yemen in pink dashed line (Manetti et al. 1991), and Syria in white stars (Krienitz et al. 2009). Alkaline-subalkaline divide is from Irvine and Baragar (1971).

Figure 15: a) $\mathrm{Zr} / \mathrm{TiO}_{2}$ versus $\mathrm{Nb} / \mathrm{Y}$ classification diagram (Winchester and Floyd 1977); b) $\mathrm{Th}_{\mathrm{N}}$ versus $\mathrm{Nb}_{\mathrm{N}}$ classification diagram (Saccani 2015). Th $\left(\mathrm{Th}_{\mathrm{N}}\right)$ and $\mathrm{Nb}\left(\mathrm{Nb}_{\mathrm{N}}\right)$ are normalised with respect to the normal MORB (Sun and McDonough 1989). MORB = midocean ridge basalt; G-MORB = garnet-influenced MORB; N-MORB = normal-type MORB; E-MORB = enriched-type MORB; p-MORB = plume-type MORB; AB = alkaline oceanisland basalt; IAT = low-Ti, island arc tholeiite; BON = very low-Ti, boninitic basalt; $\mathrm{CAB}=$ calc-alkaline basalt; MTB = medium-Ti basalt; D-MORB = depleted-type MORB; BABB = back arc basin basalt.

Figure 16: a) $\mathrm{FeO}^{\text {tot }} /\left(\mathrm{FeO}^{\text {tot }}+\mathrm{MgO}\right.$ ) versus $\mathrm{SiO}_{2}$ classification diagram (Frost et al. 2001); b) $\mathrm{Na}_{2} \mathrm{O}+\mathrm{K}_{2} \mathrm{O}-\mathrm{CaO}$ versus $\mathrm{SiO}_{2}$ classification diagram (Frost et al. 2001); c) classification diagram Rb/Nb versus Y/Nb (Eby 1992); A1 = magmas emplaced during continental rifting or intraplate; A2 = continent/continent collision or island arc magmatism.

Figure 17: AFM diagram $\left(\mathrm{A}=\mathrm{K}_{2} \mathrm{O} \mathrm{Na} \mathrm{Na}_{2} \mathrm{O} ; \mathrm{F}=\mathrm{FeO} ; \mathrm{M}=\mathrm{MgO}\right)$. $\mathrm{FeO}$ is the total iron as recommended for AFM diagram by Rollinson (1993). The black line is the divide of tholeiitic and calcalkaline series after Irvine and Baragar (1971).

\section{Table captions}

Table 1: U-Pb isotopic data and calculated ages for samples AP-03, AP-05, and AP-14.

Table 2: Standards used for U-Pb geochronology.

Table 3: Representative analyses of amphibole. Sample label: first 5 digits are sample number; last three digits are point analyses.

Table 4: Representative analyses of pyroxene and epidote. Sample label: first 5 digits are sample number; last three digits are point analyses. 
Table 5: Representative analyses of feldspars. Sample label: first 5 digits are sample number; last three digits are point analyses.

Table 6: Representative analyses of olivine, biotite, chlorite, and white mica. Sample label: first 5 digits are sample number; last three digits are point analyses.

Table 7: Analyses of glass. The microstructural position is indicated for any point analysis. Sample label: first 5 digits are sample number; last three digits are point analyses.

Table 8: major and trace elements for two basic dykes (AP-01 and AP-08), intermediate dykes (AP-18, AP-19, and AP-20), and two rhyolitic dykes (AP-16 and AP-17). Note that in Figs. 14, 15, and 16, major elements were normalised to $100 \%$ without considering loss on ignition (LOI).

Table 9: summary of the dyke features for each sample with possible tectonic interpretation. Asterisk indicates the dyke that turned out to be Neaproterozoic in age after radiometric age testing. 


\section{Suturing}

Extension

$\frac{500 \quad 550 \quad 60}{11}$

\section{Precratonic assemblage}

700

750

800

850

900

Time (Ma) 


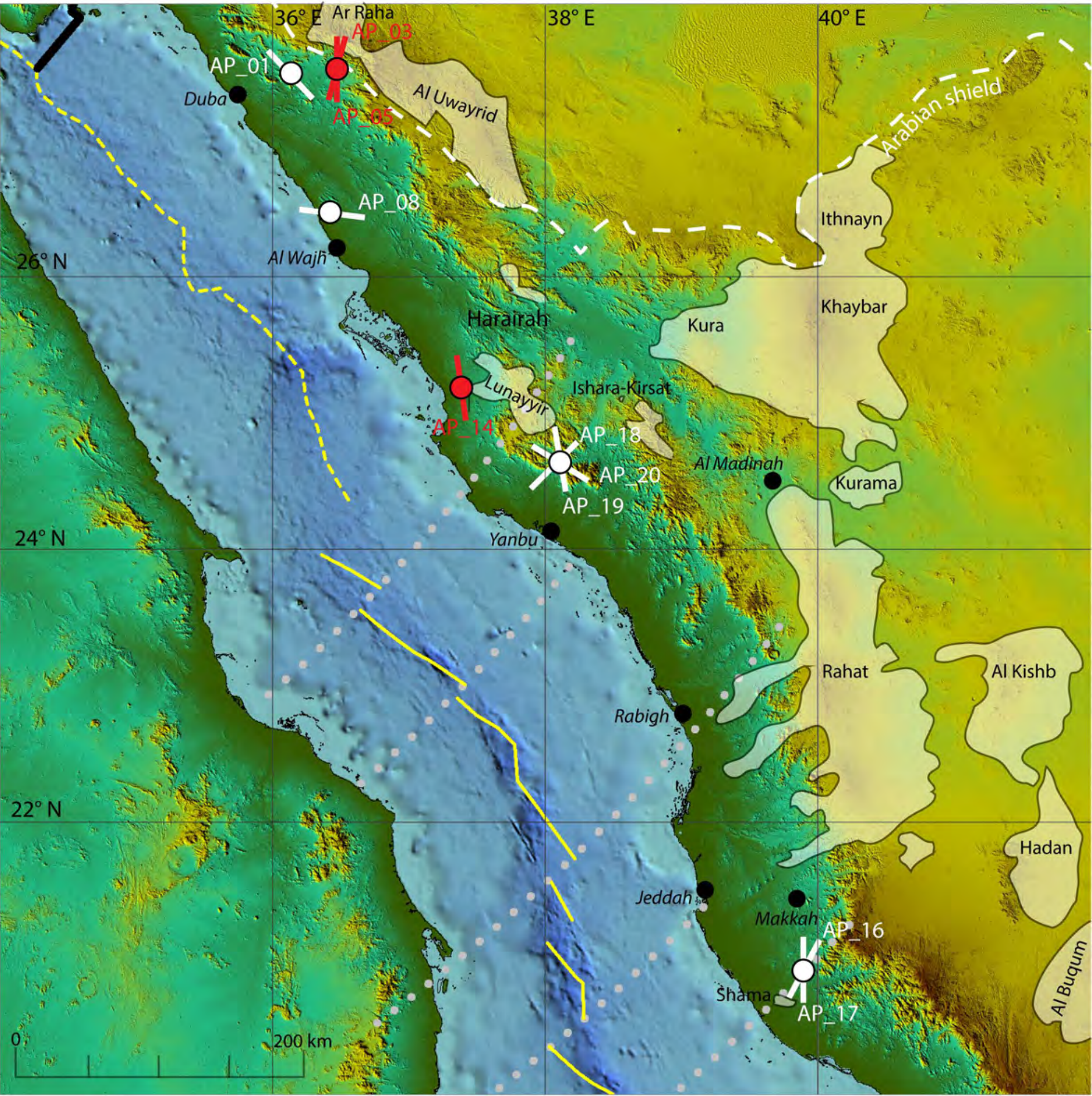




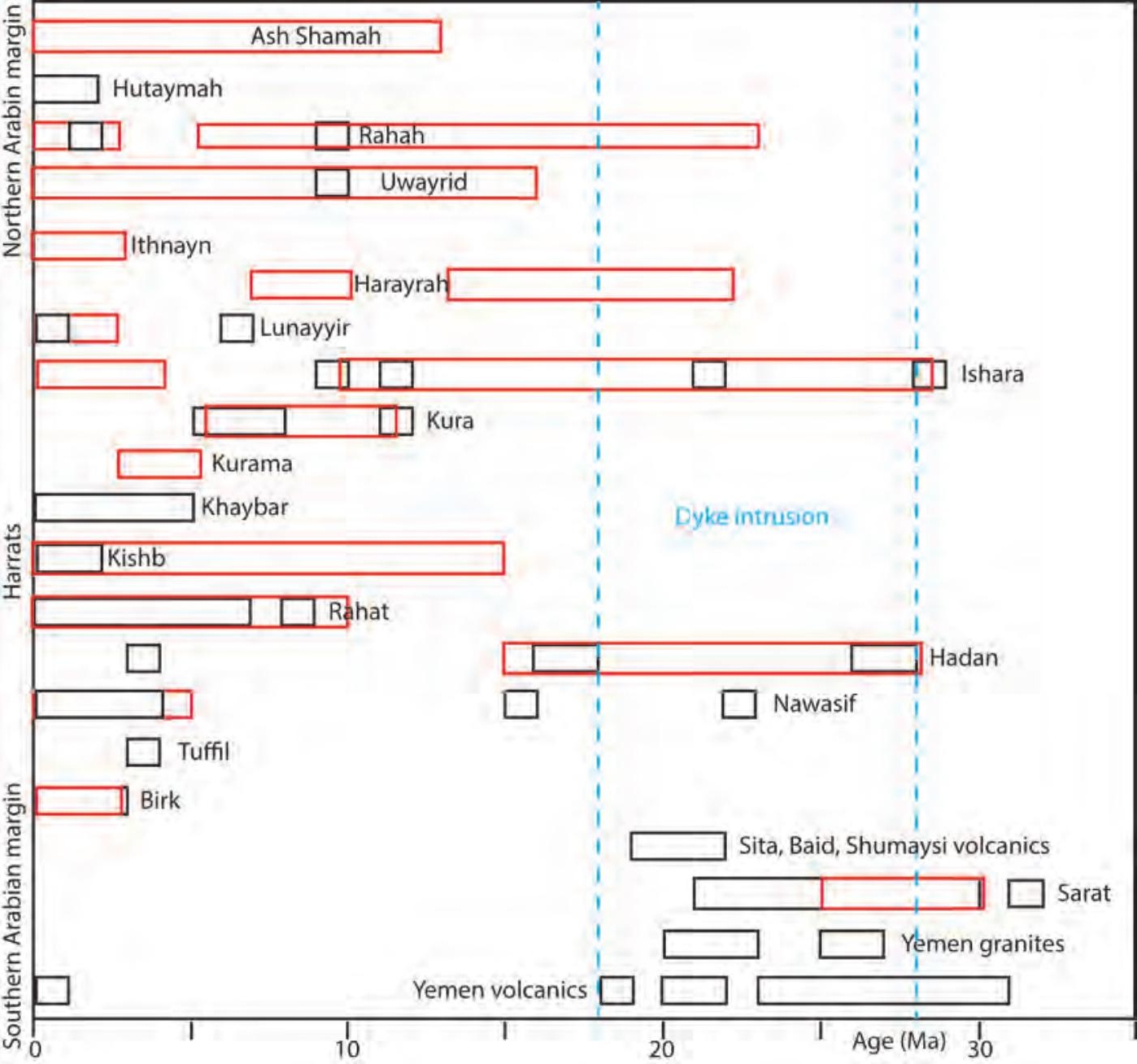


(a)

(b)

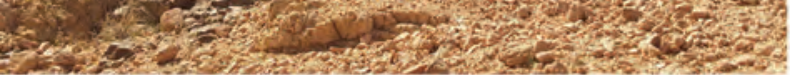

(c)

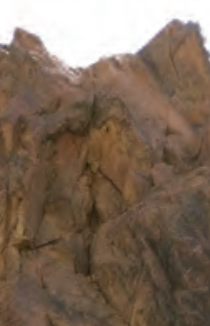

1.

$1 x^{2}+x^{3}$

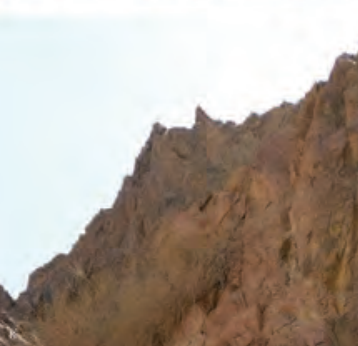

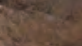

(e)
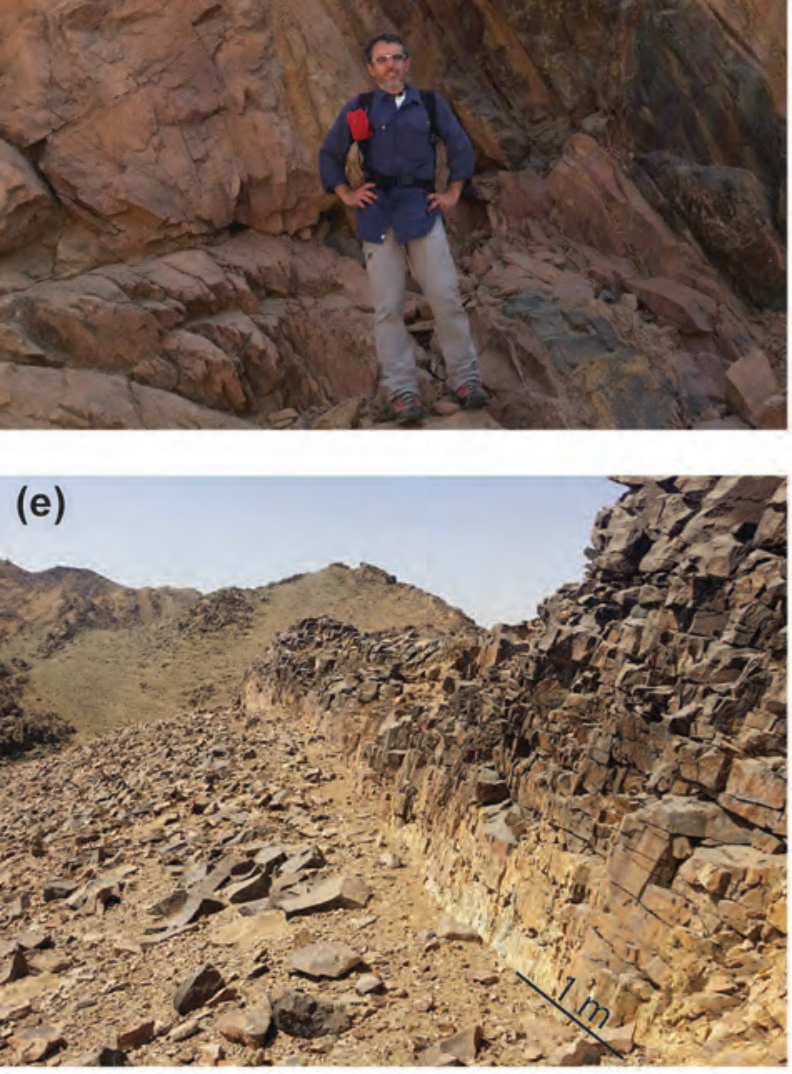

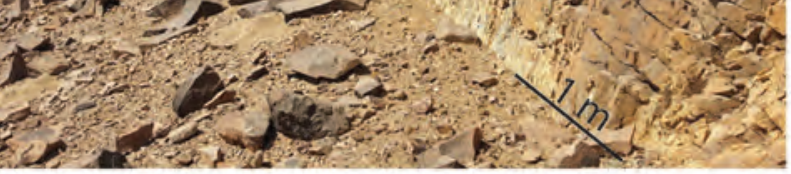

(a) 1 (1)

He

(19)

(f)

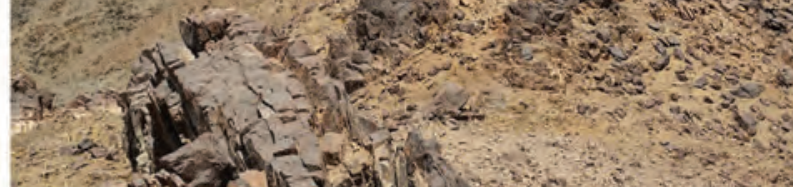

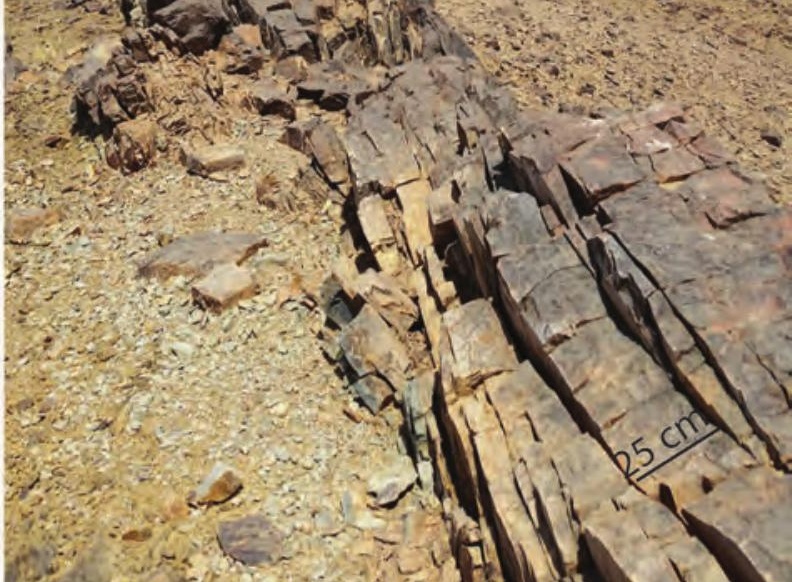



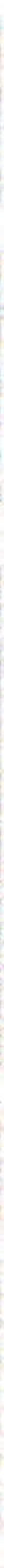

(f)

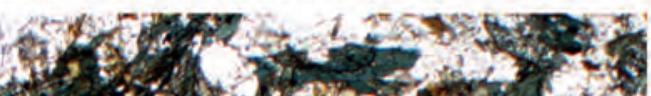

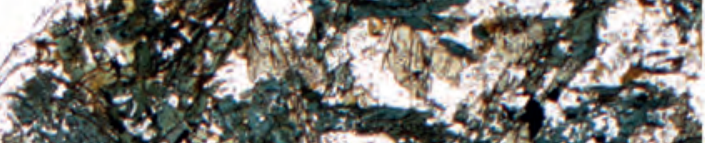

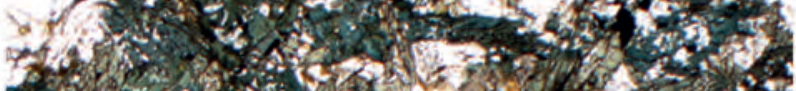

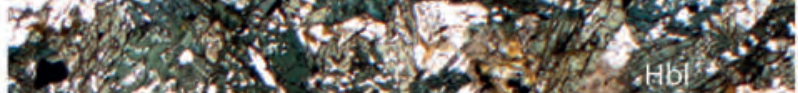

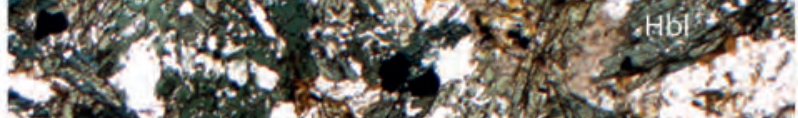

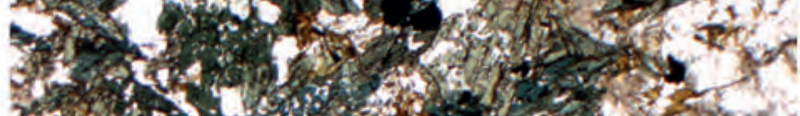

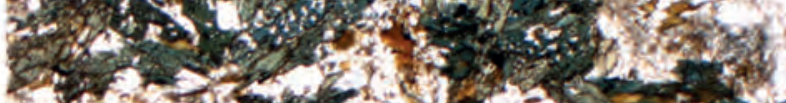
2. 50 $4 y^{-5}+y^{2}$ 


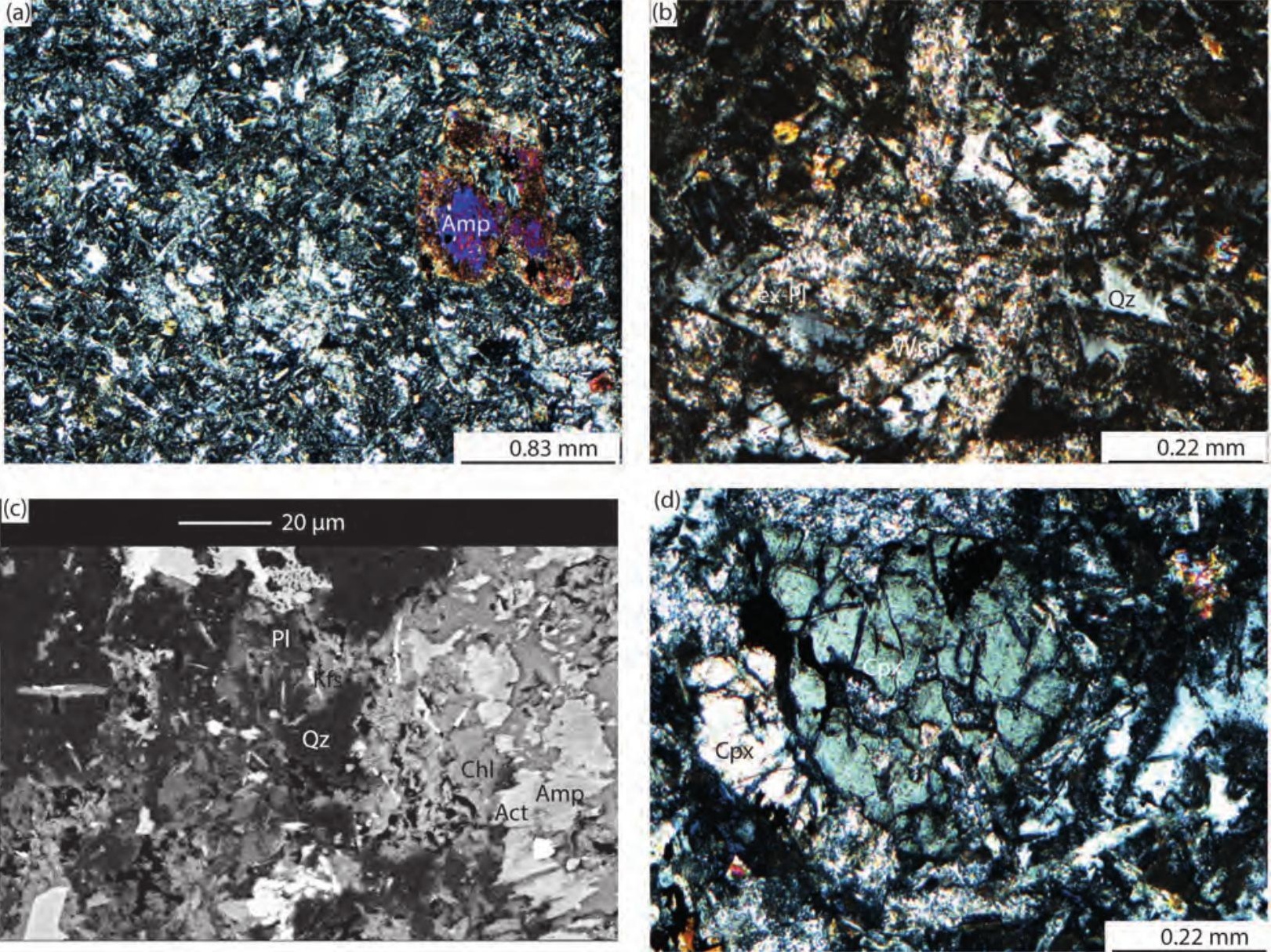




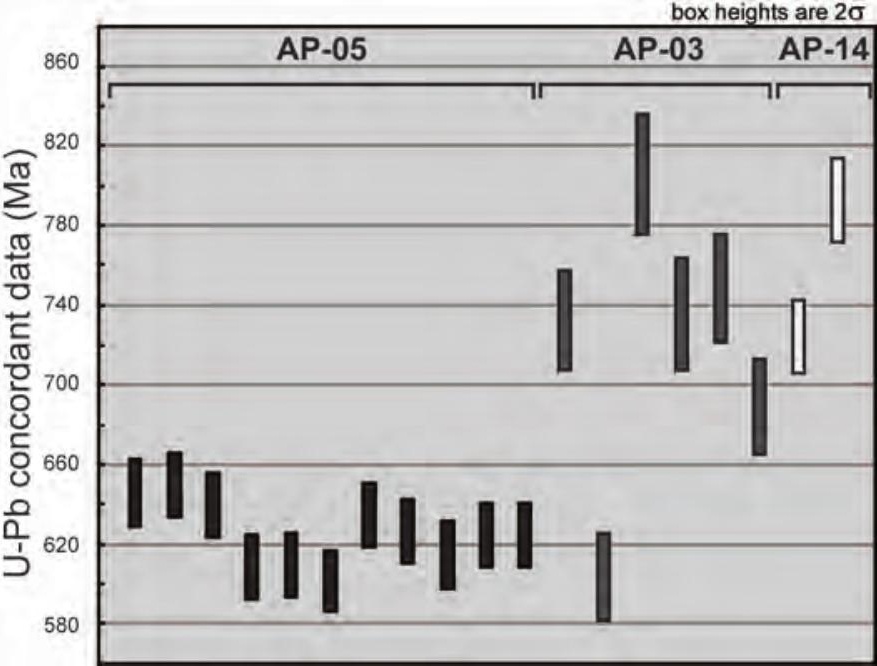



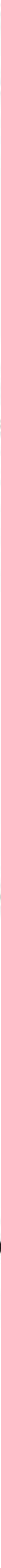

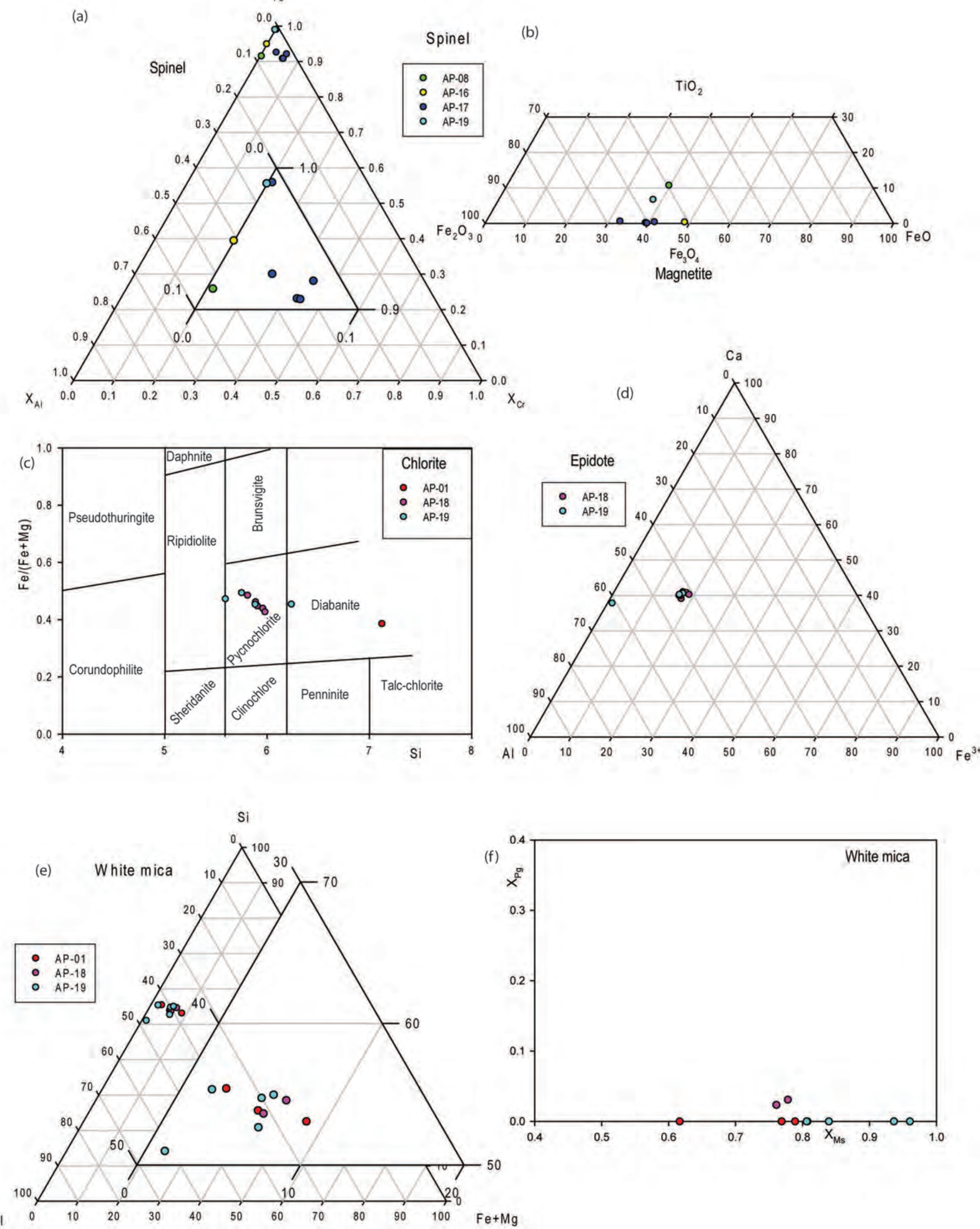


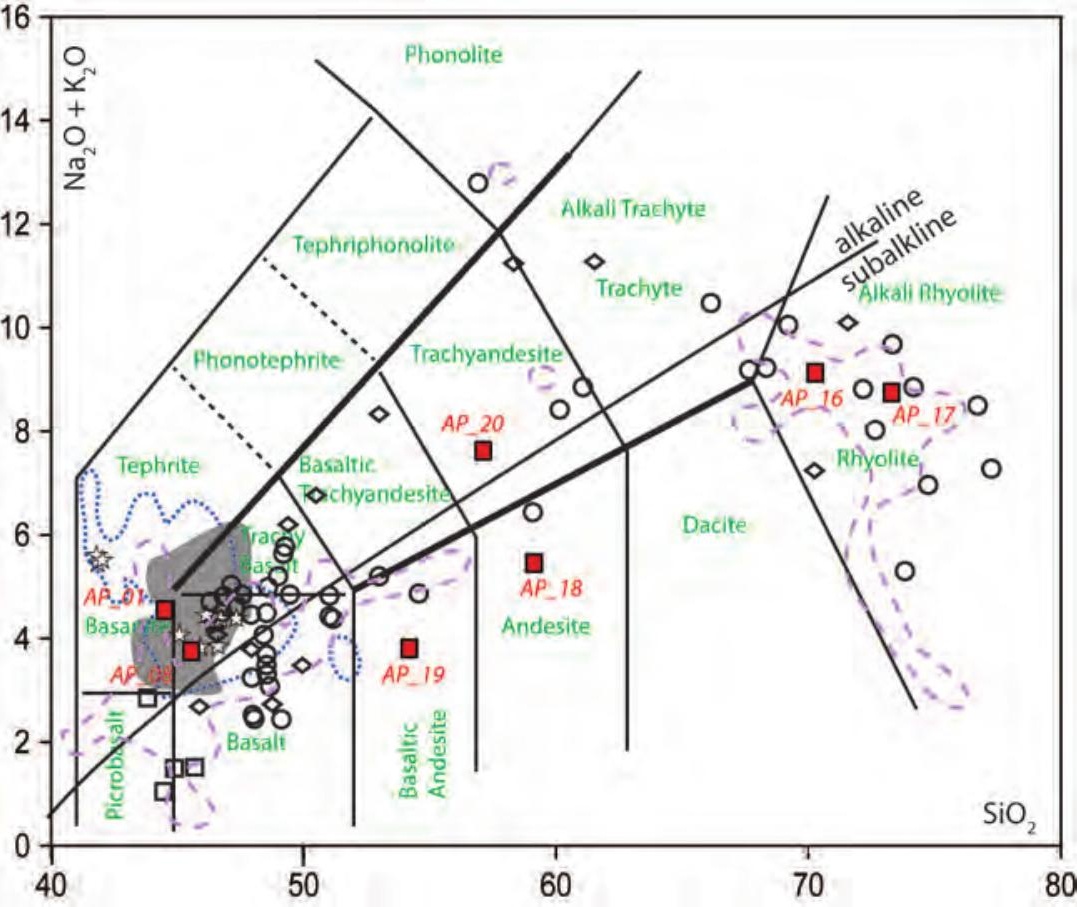



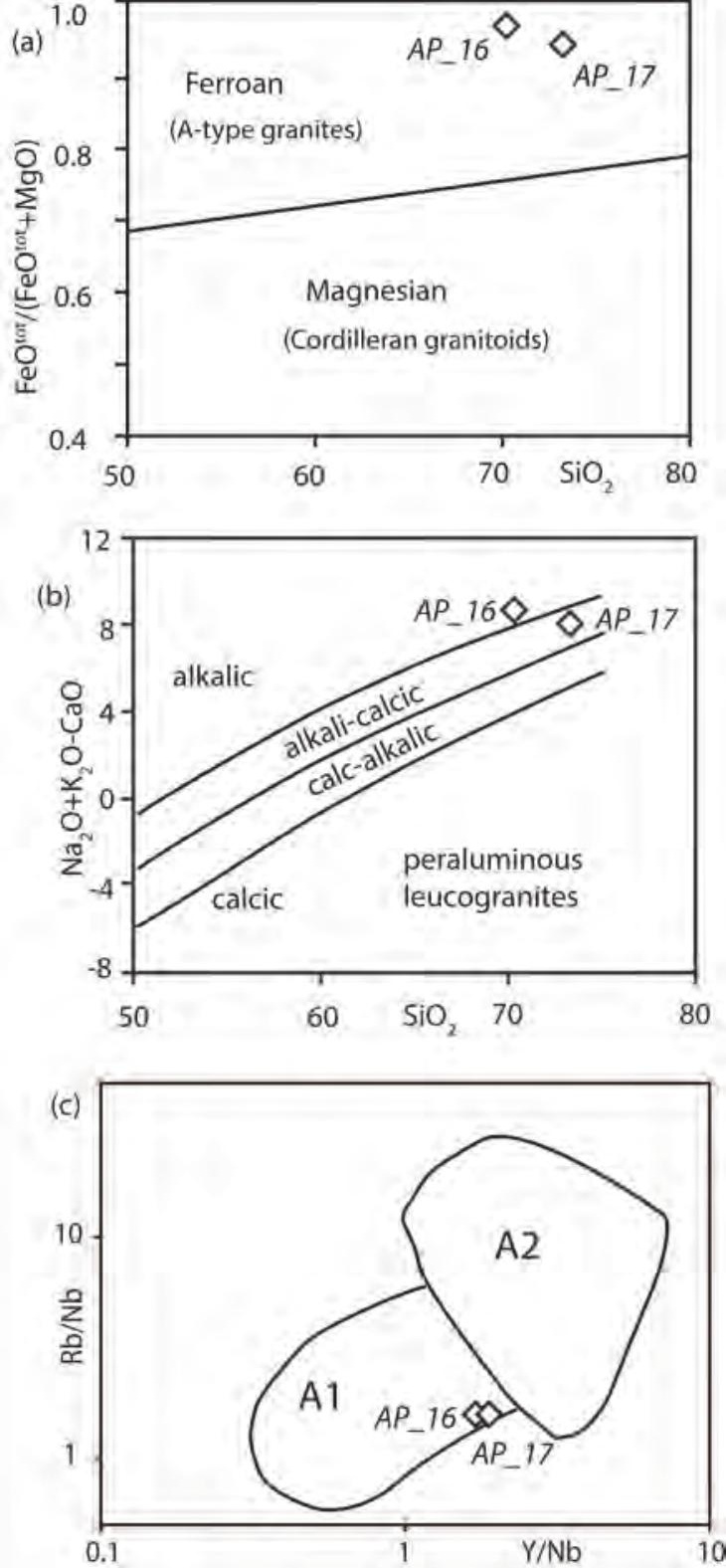


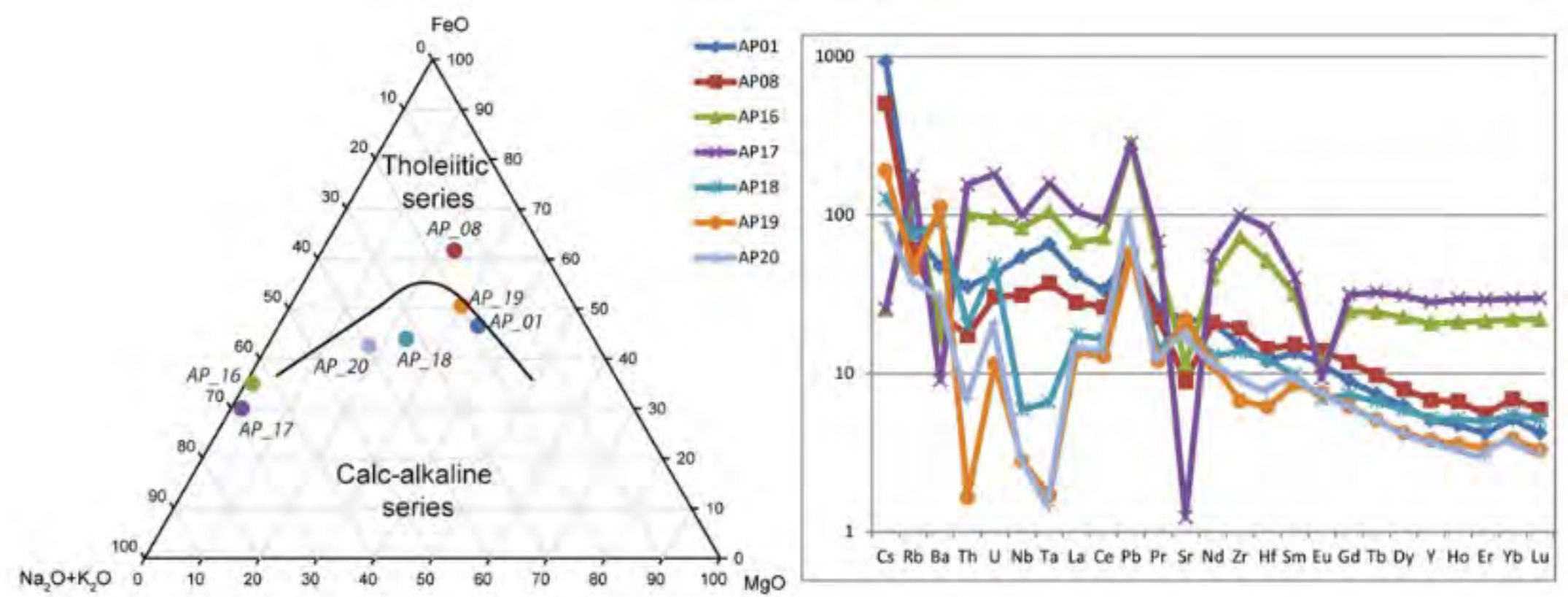




\begin{tabular}{|c|c|c|c|c|c|c|c|c|c|c|c|c|c|c|c|c|c|c|}
\hline $\begin{array}{l}\text { 24th Se } \\
\text { Sample }\end{array}$ & $\begin{array}{r}\text { ptember } 2 \\
\text { Identifier }\end{array}$ & $\begin{array}{l}15, \mathrm{IG} \\
\mathrm{Zrc \#}\end{array}$ & $\begin{array}{l}\text { G-CNR U.C } \\
{ }^{07} \mathrm{~Pb} /{ }^{206} \mathrm{Pk} \\
\end{array}$ & $\begin{array}{l}\text { O.S. of P } \\
1 \square \text { abs }\end{array}$ & ${ }^{207} \mathrm{~Pb} /{ }^{235} \mathrm{U}$ & \multicolumn{3}{|c|}{ Data for Wetherill plot ${ }^{3}$} & Rho & \multicolumn{6}{|c|}{ Ages $^{3}$} & $\%$ U-Pb disc ${ }^{4}$ & \multicolumn{2}{|c|}{$\begin{array}{r}\text { Concordant ages } \\
2 \square \text { abs } \\
\end{array}$} \\
\hline AP-05 & Se24a006 & 1 & 0.06286 & 0.00117 & 0.88477 & 0.01827 & 0.10206 & 0.00154 & 0.7 & 703 & 13 & 644 & 13 & 626 & 9 & 2.7 & & \\
\hline AP-05 & Se24a007 & 2 & 0.06051 & 0.00094 & 0.88527 & 0.01608 & 0.10606 & 0.00158 & 0.8 & 622 & 10 & 644 & 12 & 650 & 10 & -0.9 & 646 & 17 \\
\hline AP-05 & Se24a008 & 3 & 0.06151 & 0.00093 & 0.89734 & 0.01573 & 0.10587 & 0.00149 & 0.8 & 657 & 10 & 650 & 11 & 649 & 9 & 0.2 & 650 & 16 \\
\hline AP-05 & Se24a009 & 4 & 0.06065 & 0.00093 & 0.87581 & 0.01552 & 0.10475 & 0.00150 & 0.8 & 627 & 10 & 639 & 11 & 642 & 9 & -0.5 & 640 & 16 \\
\hline AP-05 & Se24a010 & 5 & 0.09040 & 0.00172 & 1.28106 & 0.02658 & 0.10276 & 0.00164 & 0.8 & 1434 & 27 & 837 & 17 & 631 & 10 & 24.7 & & \\
\hline AP-05 & Se24a011 & 6 & 0.05977 & 0.00095 & 0.81905 & 0.01506 & 0.09935 & 0.00146 & 0.8 & 595 & 9 & 608 & 11 & 611 & 9 & -0.5 & 609 & 16 \\
\hline AP-05 & Se24a012 & 7 & 0.06009 & 0.00092 & 0.82213 & 0.01461 & 0.09927 & 0.00144 & 0.8 & 607 & 9 & 609 & 11 & 610 & 9 & -0.1 & 610 & 16 \\
\hline AP-05 & Se24a013 & 8 & 0.05478 & 0.00084 & 0.77893 & 0.01401 & 0.10311 & 0.00151 & 0.8 & 403 & 6 & 585 & 11 & 633 & 9 & -8.2 & & \\
\hline AP-05 & Se24a014 & 9 & 0.07576 & 0.00114 & 0.57120 & 0.01017 & 0.05465 & 0.00082 & 0.8 & 1089 & 16 & 459 & 8 & 343 & 5 & 25.2 & & \\
\hline AP-05 & Se24a015 & 10 & 0.06333 & 0.00128 & 0.86362 & 0.01910 & 0.09883 & 0.00152 & 0.7 & 719 & 15 & 632 & 14 & 608 & 9 & 3.9 & & \\
\hline AP-05 & Se24a016 & 11 & 0.05910 & 0.00088 & 0.80404 & 0.01389 & 0.09870 & 0.00138 & 0.8 & 571 & 8 & 599 & 10 & 607 & 8 & -1.3 & 602 & 15 \\
\hline AP-05 & Se24a017 & $12 a$ & 0.06037 & 0.00092 & 0.86481 & 0.01527 & 0.10395 & 0.00146 & 0.8 & 617 & 9 & 633 & 11 & 638 & 9 & -0.8 & 635 & 16 \\
\hline AP-05 & Se24a018 & $12 b$ & 0.06105 & 0.00097 & 0.85751 & 0.01562 & 0.10190 & 0.00144 & 0.8 & 641 & 10 & 629 & 11 & 626 & 9 & 0.5 & 627 & 16 \\
\hline AP-05 & Se24a019 & 13 & 0.09201 & 0.00158 & 0.77158 & 0.01508 & 0.06079 & 0.00093 & 0.8 & 1468 & 25 & 581 & 11 & 380 & 6 & 34.5 & & \\
\hline AP-05 & Se24a020 & 14 & 0.07059 & 0.00099 & 0.71568 & 0.01193 & 0.07353 & 0.00103 & 0.8 & 946 & 13 & 548 & 9 & 457 & 6 & 16.6 & & \\
\hline AP-05 & Se24a021 & 15 & 0.05981 & 0.00109 & 0.82738 & 0.01696 & 0.10030 & 0.00149 & 0.7 & 597 & 11 & 612 & 13 & 616 & 9 & -0.7 & 615 & 17 \\
\hline AP-05 & Se24a022 & 16 & 0.06016 & 0.00099 & 0.84603 & 0.01572 & 0.10208 & 0.00144 & 0.8 & 609 & 10 & 622 & 12 & 627 & 9 & -0.7 & 625 & 16 \\
\hline AP-05 & Se24a023 & 17 & 0.06079 & 0.00105 & 0.85211 & 0.01643 & 0.10175 & 0.00144 & 0.7 & 632 & 11 & 626 & 12 & 625 & 9 & 0.2 & 625 & 16 \\
\hline AP-03 & Se24b006 & 1 & 0.06468 & 0.00143 & 1.06700 & 0.03232 & 0.11996 & 0.00222 & 0.6 & 764 & 17 & 737 & 22 & 730 & 14 & 0.9 & 732 & 25 \\
\hline AP-03 & Se24b007 & 2 & 0.12895 & 0.00239 & 2.34674 & 0.06497 & 0.13210 & 0.00245 & 0.7 & 2084 & 39 & 1227 & 34 & 800 & 15 & 34.8 & & \\
\hline AP-03 & Se24b008 & 3 & 0.24758 & 0.00433 & 5.11647 & 0.13800 & 0.15049 & 0.00271 & 0.7 & 3169 & 55 & 1839 & 50 & 904 & 16 & 50.9 & & \\
\hline AP-03 & Se24b009 & 4 & 0.23574 & 0.00443 & 4.28480 & 0.11801 & 0.13205 & 0.00236 & 0.6 & 3091 & 58 & 1690 & 47 & 800 & 14 & 52.7 & & \\
\hline AP-03 & Se24b010 & $5 a$ & 0.09653 & 0.00280 & 1.57762 & 0.05501 & 0.11846 & 0.00220 & 0.5 & 1558 & 45 & 961 & 34 & 722 & 13 & 24.9 & & \\
\hline AP-03 & Se24b011 & $5 b$ & 0.05984 & 0.00168 & 0.81068 & 0.02782 & 0.09828 & 0.00191 & 0.6 & 598 & 17 & 603 & 21 & 604 & 12 & -0.2 & 604 & 22 \\
\hline AP-03 & Se24b012 & 6 & 0.18133 & 0.00597 & 2.87623 & 0.10701 & 0.11514 & 0.00253 & 0.6 & 2665 & 88 & 1376 & 51 & 703 & 15 & 48.9 & & \\
\hline AP-03 & Se24b015 & 9 & 0.06608 & 0.00242 & 1.21282 & 0.05018 & 0.13303 & 0.00264 & 0.5 & 809 & 30 & 806 & 33 & 805 & 16 & 0.2 & 805 & 30 \\
\hline AP-03 & Se24b017 & 11 & 0.12814 & 0.00227 & 2.14304 & 0.05853 & 0.12147 & 0.00221 & 0.7 & 2073 & 37 & 1163 & 32 & 739 & 13 & 36.4 & & \\
\hline AP-03 & Se24b020 & 14 & 0.11664 & 0.00224 & 2.25379 & 0.06346 & 0.14008 & 0.00253 & 0.6 & 1905 & 37 & 1198 & 34 & 845 & 15 & 29.5 & & \\
\hline AP-03 & Se24b022 & $16 a$ & 0.06414 & 0.00290 & 1.06791 & 0.05216 & 0.12080 & 0.00245 & 0.4 & 746 & 34 & 738 & 36 & 735 & 15 & 0.3 & 735 & 28 \\
\hline AP-03 & Se24b023 & $16 b$ & 0.06974 & 0.00190 & 1.12459 & 0.03796 & 0.11688 & 0.00213 & 0.5 & 921 & 25 & 765 & 26 & 713 & 13 & 6.9 & & \\
\hline AP-03 & Se24b024 & 17 & 0.06496 & 0.00128 & 1.03918 & 0.02965 & 0.11599 & 0.00205 & 0.6 & 773 & 15 & 724 & 21 & 707 & 13 & 2.2 & & \\
\hline AP-03 & Se24b025 & $18 a$ & 0.06442 & 0.00228 & 1.09203 & 0.04425 & 0.12290 & 0.00237 & 0.5 & 755 & 27 & 749 & 30 & 747 & 14 & 0.3 & 748 & 27 \\
\hline AP-03 & Se24b026 & $18 b$ & 0.07580 & 0.00175 & 1.30455 & 0.03988 & 0.12478 & 0.00220 & 0.6 & 1090 & 25 & 848 & 26 & 758 & 13 & 10.6 & & \\
\hline AP-03 & Se24b027 & $18 \mathrm{c}$ & 0.07620 & 0.00418 & 1.34725 & 0.07694 & 0.12806 & 0.00291 & 0.4 & 1100 & 60 & 866 & 49 & 777 & 18 & 10.3 & & \\
\hline AP-03 & Se24b028 & $19 a$ & 0.14380 & 0.00255 & 2.38235 & 0.06504 & 0.11992 & 0.00216 & 0.7 & 2273 & 40 & 1237 & 34 & 730 & 13 & 41.0 & & \\
\hline AP-03 & Se24b029 & $19 b$ & 0.06224 & 0.00201 & 0.96873 & 0.03666 & 0.11290 & 0.00211 & 0.5 & 682 & 22 & 688 & 26 & 690 & 13 & -0.3 & 689 & 24 \\
\hline AP-03 & Se24b030 & 20 & 0.25056 & 0.00418 & 5.74509 & 0.15170 & 0.16628 & 0.00289 & 0.7 & 3188 & 53 & 1938 & 51 & 992 & 17 & 48.8 & & \\
\hline AP-14 & Se24c008 & $1 a$ & 0.06374 & 0.00167 & 1.04461 & 0.02924 & 0.11886 & 0.00159 & 0.5 & 733 & 19 & 726 & 20 & 724 & 10 & 0.3 & 724 & 18 \\
\hline AP-14 & Se24c009 & $1 b$ & 0.06527 & 0.00174 & 1.17803 & 0.03399 & 0.13085 & 0.00191 & 0.5 & 783 & 21 & 790 & 23 & 793 & 12 & -0.3 & 792 & 21 \\
\hline
\end{tabular}




\begin{tabular}{|c|c|c|c|c|c|c|c|c|c|c|c|c|c|c|c|c|}
\hline & \multirow{2}{*}{\multicolumn{3}{|c|}{${ }^{207} \mathrm{~Pb} /{ }^{206} \mathrm{~Pb}$}} & \multirow{2}{*}{\multicolumn{3}{|c|}{${ }^{207} \mathrm{~Pb} /{ }^{235} \mathrm{U}$}} & \multirow{2}{*}{\multicolumn{3}{|c|}{${ }^{206} \mathrm{~Pb} /{ }^{238} \mathrm{U}$}} & \multirow{2}{*}{\multicolumn{5}{|c|}{ Ages }} \\
\hline & & & & & & & & & & & & & & & & \\
\hline \multicolumn{3}{|c|}{24 September 2015, IGG-CNR U.O.S. of Pavia } & Ratio & $1 \square \%$ & $1 \square \%$ (Prop) & Ratio & $1 \square \%$ & $1 \square \%$ (Prop) & Ratio & $1 \square \%$ & $1 \square \%$ (Prop) & ${ }^{207} \mathrm{~Pb} /{ }^{206} \mathrm{~Pb} 1$ & $\mathrm{abs}^{207}$ & ${ }^{77} \mathrm{~Pb} /{ }^{235}$ & $\mathrm{U} 1 \square \mathrm{abs}^{206}$ & ${ }^{6} \mathrm{~Pb} /{ }^{238} \mathrm{U}$ \\
\hline Se24a001 & GJ-1 & Begin & \begin{tabular}{|l|}
0.05996 \\
\end{tabular} & $0.06 \%$ & $0.08 \%$ & 0.7994 & $0.92 \%$ & $1.31 \%$ & 0.0967 & $0.12 \%$ & $0.13 \%$ & 602 & 8 & 596 & 10 & 595 \\
\hline Se24a002 & GJ-1 & Begin & 0.06007 & $0.06 \%$ & $0.09 \%$ & 0.8147 & $0.96 \%$ & $1.35 \%$ & 0.0984 & $0.12 \%$ & $0.14 \%$ & 606 & 9 & 605 & 10 & 605 \\
\hline $\mathrm{Se} 24 \mathrm{a} 003$ & GJ-1 & Begin & 0.06041 & $0.06 \%$ & $0.09 \%$ & 0.8186 & $0.98 \%$ & $1.37 \%$ & 0.0983 & $0.12 \%$ & $0.14 \%$ & 618 & 9 & 607 & 10 & 604 \\
\hline Se24a004 & GJ-1 & Begin & 0.06024 & $0.06 \%$ & $0.09 \%$ & 0.8111 & $0.96 \%$ & $1.35 \%$ & 0.0977 & $0.12 \%$ & $0.14 \%$ & 612 & 9 & 603 & 10 & 601 \\
\hline Se24a026 & GJ-1 & End & 0.06080 & $0.07 \%$ & $0.09 \%$ & 0.814 & $1.06 \%$ & $1.43 \%$ & 0.0971 & $0.12 \%$ & $0.14 \%$ & 632 & 10 & 605 & 11 & 598 \\
\hline Se24a027 & GJ-1 & End & 0.05897 & $0.07 \%$ & $0.09 \%$ & 0.7941 & $1.06 \%$ & $1.40 \%$ & 0.0977 & $0.12 \%$ & $0.14 \%$ & 566 & 9 & 593 & 10 & 601 \\
\hline $\mathrm{Se} 24 \mathrm{a} 028$ & GJ-1 & End & 0.06055 & $0.07 \%$ & $0.09 \%$ & 0.8175 & $1.08 \%$ & $1.44 \%$ & 0.0979 & $0.12 \%$ & $0.14 \%$ & 623 & 10 & 607 & 11 & 602 \\
\hline Se24b002 & GJ-1 & Begin & 0.06088 & $0.07 \%$ & $0.10 \%$ & 0.8315 & $1.06 \%$ & $2.18 \%$ & 0.099 & $0.12 \%$ & $0.17 \%$ & 635 & 11 & 614 & 16 & 609 \\
\hline $\mathrm{Se} 24 \mathrm{~b} 003$ & GJ-1 & Begin & 0.05891 & $0.07 \%$ & $0.10 \%$ & 0.7843 & $1.03 \%$ & $2.07 \%$ & 0.0965 & $0.12 \%$ & $0.17 \%$ & 564 & 9 & 588 & 16 & 594 \\
\hline Se24b004 & GJ-1 & Begin & 0.06061 & $0.07 \%$ & $0.10 \%$ & 0.8167 & $1.08 \%$ & $2.16 \%$ & 0.0977 & $0.13 \%$ & $0.17 \%$ & 625 & 10 & 606 & 16 & 601 \\
\hline Se24b032 & GJ-1 & End & 0.06036 & $0.07 \%$ & $0.10 \%$ & 0.8208 & $1.13 \%$ & $2.20 \%$ & 0.0986 & $0.13 \%$ & $0.17 \%$ & 617 & 11 & 608 & 16 & 606 \\
\hline Se24b034 & GJ-1 & End & 0.06047 & $0.07 \%$ & $0.10 \%$ & 0.8204 & $1.13 \%$ & $2.19 \%$ & 0.0984 & $0.13 \%$ & $0.17 \%$ & 620 & 11 & 608 & 16 & 605 \\
\hline Se24b035 & GJ-1 & End & 0.05957 & $0.07 \%$ & $0.10 \%$ & 0.7914 & $1.08 \%$ & $2.11 \%$ & 0.0963 & $0.12 \%$ & $0.17 \%$ & 588 & 10 & 592 & 16 & 593 \\
\hline Se24c004 & GJ-1 & Begin & 0.05991 & $0.08 \%$ & $0.16 \%$ & 0.8122 & $1.17 \%$ & $2.36 \%$ & 0.0983 & $0.13 \%$ & $0.14 \%$ & 600 & 16 & 604 & 18 & 605 \\
\hline Se24c005 & GJ-1 & Begin & 0.06022 & $0.08 \%$ & $0.16 \%$ & 0.8044 & $1.15 \%$ & $2.34 \%$ & 0.0969 & $0.12 \%$ & $0.14 \%$ & 611 & 17 & 599 & 17 & 596 \\
\hline Se24c014 & GJ-1 & End & 0.06210 & $0.08 \%$ & $0.17 \%$ & 0.8371 & $1.24 \%$ & $2.46 \%$ & 0.0978 & $0.12 \%$ & $0.14 \%$ & 678 & 19 & 618 & 18 & 601 \\
\hline Se24c015 & GJ-1 & End & 0.05858 & $0.08 \%$ & $0.16 \%$ & 0.7878 & $1.18 \%$ & $2.32 \%$ & 0.0976 & $0.12 \%$ & $0.14 \%$ & 552 & 15 & 590 & 17 & 600 \\
\hline Se24a024 & 02123 & End & 0.05241 & & $0.21 \%$ & 0.35045 & & $1.41 \%$ & 0.04849 & & $0.08 \%$ & 303 & 12 & 305 & 12 & 305 \\
\hline Se24b005 & 02123 & Begin & 0.05529 & & $0.10 \%$ & 0.35516 & & $0.97 \%$ & 0.04656 & & $0.08 \%$ & 424 & 8 & 309 & 8 & 293 \\
\hline Se24c006 & 02123 & Begin & 0.05184 & & $0.20 \%$ & 0.33359 & & $1.30 \%$ & 0.04674 & & $0.08 \%$ & 278 & 11 & 292 & 11 & 294 \\
\hline
\end{tabular}


Amphibole

Sample label AP_01_13 AP_08_57 AP_18_20

\begin{tabular}{|c|c|c|c|}
\hline $\mathrm{SiO}_{2}$ & 40.07 & 42.25 & 51.02 \\
\hline $\mathrm{TiO}_{2}$ & 5.37 & 3.67 & 0.74 \\
\hline $\mathrm{Al}_{2} \mathrm{O}_{3}$ & 12.11 & 13.17 & 4.19 \\
\hline $\mathrm{Cr}_{2} \mathrm{O}_{3}$ & 0.00 & 0.27 & 0.03 \\
\hline $\mathrm{MnO}$ & 0.33 & 0.30 & 0.48 \\
\hline $\mathrm{FeO}$ & 16.05 & 9.56 & 10.84 \\
\hline $\mathrm{Fe}_{2} \mathrm{O}_{3}$ & 1.92 & 1.44 & 4.39 \\
\hline $\mathrm{NiO}$ & 0.02 & 0.13 & 0.00 \\
\hline $\mathrm{MgO}$ & 8.79 & 13.56 & 14.36 \\
\hline $\mathrm{CaO}$ & 11.80 & 12.04 & 12.51 \\
\hline $\mathrm{Na}_{2} \mathrm{O}$ & 0.94 & 1.90 & 0.27 \\
\hline $\mathrm{K}_{2} \mathrm{O}$ & 0.94 & 0.53 & 0.19 \\
\hline Total & 98.33 & 98.83 & 99.02 \\
\hline \multicolumn{4}{|l|}{$\mathrm{T}$ site } \\
\hline Si & 6.03 & 6.12 & 7.32 \\
\hline $\mathrm{Al}$ & 1.97 & 1.88 & 0.68 \\
\hline \multicolumn{4}{|l|}{ C site } \\
\hline $\mathrm{Ti}$ & 0.61 & 0.40 & 0.08 \\
\hline $\mathrm{Al}$ & 0.18 & 0.36 & 0.03 \\
\hline $\mathrm{Cr}$ & 0.00 & 0.03 & 0.00 \\
\hline $\mathrm{Fe}^{3+}$ & 0.22 & 0.16 & 0.48 \\
\hline $\mathrm{Ni}$ & 0.00 & 0.02 & 0.00 \\
\hline $\mathrm{Mn}^{2+}$ & 0.00 & 0.00 & 0.04 \\
\hline $\mathrm{Fe}^{2+}$ & 2.02 & 1.11 & 1.30 \\
\hline $\mathrm{Mg}$ & 1.97 & 2.93 & 3.07 \\
\hline \multicolumn{4}{|l|}{ B site } \\
\hline $\mathrm{Mn}^{2+}$ & 0.04 & 0.04 & 0.02 \\
\hline $\mathrm{Fe}^{2+}$ & 0.00 & 0.05 & 0.00 \\
\hline $\mathrm{Ca}$ & 1.90 & 1.87 & 1.92 \\
\hline $\mathrm{Na}$ & 0.05 & 0.05 & 0.05 \\
\hline \multicolumn{4}{|l|}{ A site } \\
\hline $\mathrm{Ca}$ & 0.00 & 0.00 & 0.00 \\
\hline $\mathrm{Na}$ & 0.22 & 0.49 & 0.02 \\
\hline $\mathrm{K}$ & 0.18 & 0.10 & 0.03 \\
\hline
\end{tabular}


Piroxene

Epidote

\begin{tabular}{|c|c|c|c|c|c|c|}
\hline Sample label & AP_01_20 & AP_08_54 & AP_08_58 & AP_18_29 & AP_18_83 & AP_19_98 \\
\hline $\mathrm{K}_{2} \mathrm{O}$ & 0.03 & 0.00 & 0.01 & 0.00 & 0.05 & 0.09 \\
\hline $\mathrm{CaO}$ & 23.44 & 0.82 & 21.18 & 20.78 & 23.72 & 23.05 \\
\hline $\mathrm{TiO}_{2}$ & 1.69 & 0.16 & 1.13 & 0.55 & 0.00 & 0.10 \\
\hline $\mathrm{Cr}_{2} \mathrm{O}_{3}$ & 0.00 & 0.05 & 0.28 & 0.07 & 0.03 & 0.00 \\
\hline $\mathrm{MnO}$ & 0.07 & 0.48 & 0.23 & 0.16 & 0.27 & 0.00 \\
\hline $\mathrm{FeO}$ & 8.75 & 20.08 & 2.70 & 7.69 & 0.00 & 0.00 \\
\hline $\mathrm{Fe}_{2} \mathrm{O}_{3}$ & 0.00 & 0.00 & 4.44 & 2.05 & 15.89 & 13.95 \\
\hline $\mathrm{NiO}$ & 0.01 & 0.03 & 0.31 & 0.20 & 0.00 & 0.00 \\
\hline $\mathrm{Na}_{2} \mathrm{O}$ & 0.00 & 0.15 & 0.70 & 0.25 & 0.02 & 0.00 \\
\hline $\mathrm{SiO}_{2}$ & 50.42 & 54.08 & 50.15 & 51.37 & 38.16 & 36.70 \\
\hline $\mathrm{Al}_{2} \mathrm{O}_{3}$ & 3.49 & 0.74 & 4.71 & 1.85 & 22.01 & 21.88 \\
\hline $\mathrm{MgO}$ & 12.73 & 23.67 & 15.33 & 14.64 & 0.01 & 0.11 \\
\hline TOTAL & 100.61 & 100.27 & 100.74 & 99.40 & 100.16 & 95.87 \\
\hline $\mathrm{Si}$ & 1.88 & 1.99 & 1.83 & 1.92 & 3.00 & 2.99 \\
\hline $\mathrm{Al}^{\mathrm{IV}}$ & 0.12 & 0.01 & 0.17 & 0.08 & 0.00 & 0.01 \\
\hline $\mathrm{Al}^{\mathrm{VI}}$ & 0.03 & 0.02 & 0.03 & 0.00 & 2.04 & 2.10 \\
\hline $\mathrm{Ti}$ & 0.05 & 0.00 & 0.03 & 0.02 & 0.00 & 0.01 \\
\hline $\mathrm{Cr}$ & 0.00 & 0.00 & 0.01 & 0.00 & 0.00 & 0.00 \\
\hline $\mathrm{Fe}^{3+}$ & 0.00 & 0.00 & 0.12 & 0.06 & 0.94 & 0.86 \\
\hline $\mathrm{Fe}^{2+}$ & 0.27 & 0.62 & 0.08 & 0.24 & 0.00 & 0.00 \\
\hline $\mathrm{Mg}$ & 0.71 & 1.30 & 0.83 & 0.82 & 0.00 & 0.01 \\
\hline $\mathrm{Ni}$ & 0.00 & 0.00 & 0.01 & 0.01 & 0.00 & 0.00 \\
\hline $\mathrm{Mn}$ & 0.00 & 0.02 & 0.01 & 0.01 & 0.02 & 0.00 \\
\hline $\mathrm{Ca}$ & 0.94 & 0.03 & 0.83 & 0.83 & 2.00 & 2.02 \\
\hline $\mathrm{Na}$ & 0.00 & 0.01 & 0.05 & 0.02 & 0.00 & 0.00 \\
\hline $\mathrm{K}$ & 0.00 & 0.00 & 0.00 & 0.00 & 0.00 & 0.01 \\
\hline
\end{tabular}


Feldspar

Sample label AP_01_6 AP_01_24 AP_08_43 AP_08_81 AP_16_65 AP_16_70 AP_19_91

\begin{tabular}{|c|c|c|c|c|c|c|c|}
\hline $\mathrm{K}_{2} \mathrm{O}$ & 0.20 & 0.39 & 0.28 & 1.39 & 15.82 & 0.05 & 0.10 \\
\hline $\mathrm{CaO}$ & 14.74 & 11.30 & 9.30 & 4.30 & 0.00 & 0.07 & 11.88 \\
\hline $\mathrm{TiO}_{2}$ & 0.02 & 0.14 & 0.07 & 0.08 & 0.12 & 0.00 & 0.13 \\
\hline $\mathrm{Cr}_{2} \mathrm{O}_{3}$ & 0.00 & 0.00 & 0.16 & 0.00 & 0.00 & 0.00 & 0.00 \\
\hline $\mathrm{MnO}$ & 0.08 & 0.00 & 0.00 & 0.00 & 0.04 & 0.03 & 0.09 \\
\hline $\mathrm{FeO}$ & 0.59 & 0.28 & 0.30 & 0.48 & 0.14 & 0.03 & 1.06 \\
\hline $\mathrm{NiO}$ & 0.07 & 0.10 & 0.04 & 0.00 & 0.19 & 0.00 & 0.00 \\
\hline $\mathrm{Na}_{2} \mathrm{O}$ & 2.74 & 4.55 & 6.79 & 8.73 & 0.43 & 11.58 & 3.97 \\
\hline $\mathrm{SiO}_{2}$ & 50.48 & 55.66 & 56.54 & 65.42 & 64.62 & 67.97 & 52.84 \\
\hline $\mathrm{Al}_{2} \mathrm{O}_{3}$ & 30.81 & 28.54 & 26.71 & 22.11 & 18.35 & 18.82 & 28.47 \\
\hline $\mathrm{MgO}$ & 0.03 & 0.00 & 0.00 & 0.03 & 0.00 & 0.00 & 0.06 \\
\hline TOTAL & 99.75 & 100.96 & 100.19 & 102.54 & 99.72 & 98.55 & 98.60 \\
\hline $\mathrm{Si}$ & 2.31 & 2.49 & 2.55 & 2.84 & 2.99 & 3.01 & 2.43 \\
\hline Al & 1.66 & 1.50 & 1.42 & 1.13 & 1.00 & 0.98 & 1.54 \\
\hline $\mathrm{Ti}$ & 0.00 & 0.00 & 0.00 & 0.00 & 0.00 & 0.00 & 0.00 \\
\hline $\mathrm{Cr}$ & 0.00 & 0.00 & 0.01 & 0.00 & 0.00 & 0.00 & 0.00 \\
\hline $\mathrm{Fe}^{2+}$ & 0.02 & 0.01 & 0.01 & 0.02 & 0.01 & 0.00 & 0.04 \\
\hline $\mathrm{Mn}$ & 0.00 & 0.00 & 0.00 & 0.00 & 0.00 & 0.00 & 0.00 \\
\hline $\mathrm{Mg}$ & 0.00 & 0.00 & 0.00 & 0.00 & 0.00 & 0.00 & 0.00 \\
\hline $\mathrm{Ni}$ & 0.00 & 0.00 & 0.00 & 0.00 & 0.01 & 0.00 & 0.00 \\
\hline $\mathrm{Ca}$ & 0.72 & 0.54 & 0.45 & 0.20 & 0.00 & 0.00 & 0.59 \\
\hline $\mathrm{Na}$ & 0.24 & 0.39 & 0.59 & 0.73 & 0.04 & 0.99 & 0.35 \\
\hline $\mathrm{K}$ & 0.01 & 0.02 & 0.02 & 0.08 & 0.94 & 0.00 & 0.01 \\
\hline$X_{A n}$ & 74.84 & 57.85 & 43.08 & 21.40 & 0.00 & 0.33 & 62.32 \\
\hline$x_{\text {Or }}$ & 1.19 & 2.32 & 1.52 & 7.61 & 96.03 & 0.28 & 0.62 \\
\hline$X_{A b}$ & 24.86 & 41.17 & 56.05 & 72.62 & 3.97 & 99.39 & 37.45 \\
\hline
\end{tabular}




\begin{tabular}{|c|c|c|c|c|c|c|c|c|}
\hline \multirow[b]{2}{*}{ Sample label } & \multirow{2}{*}{$\begin{array}{l}\text { Olivine } \\
\text { AP_01_35 }\end{array}$} & \multirow{2}{*}{\begin{tabular}{|l} 
Biotite \\
AP_01_29
\end{tabular}} & \multicolumn{4}{|l|}{ Chlorite } & \multicolumn{2}{|l|}{ White mica } \\
\hline & & & AP_01_41 & AP_18_84 & AP_18_93 & AP_19_90 & AP_01_1 & AP_19_83 \\
\hline $\mathrm{SiO}_{2}$ & 37.88 & 35.73 & 35.17 & 30.22 & 25.76 & 30.45 & 47.71 & 48.04 \\
\hline $\mathrm{TiO}_{2}$ & 0.00 & 0.84 & 0.13 & 0.10 & 0.00 & 0.17 & 0.06 & 0.10 \\
\hline $\mathrm{Al}_{2} \mathrm{O}_{3}$ & 0.08 & 13.11 & 13.44 & 18.72 & 17.06 & 18.57 & 29.07 & 29.80 \\
\hline $\mathrm{FeO}$ & 28.04 & 22.82 & 19.67 & 23.58 & 21.76 & 22.69 & 4.50 & 3.24 \\
\hline $\mathrm{MnO}$ & 0.46 & 0.13 & 0.19 & 0.54 & 0.52 & 0.23 & 0.00 & 0.00 \\
\hline $\mathrm{MgO}$ & 34.76 & 13.25 & 17.68 & 17.85 & 14.30 & 15.40 & 2.83 & 1.31 \\
\hline $\mathrm{CaO}$ & 0.45 & 0.07 & 0.22 & 0.21 & 0.24 & 0.39 & 2.06 & 0.00 \\
\hline $\mathrm{Na}_{2} \mathrm{O}$ & 0.00 & 0.00 & 0.00 & 0.54 & 0.53 & 0.00 & 0.00 & 0.00 \\
\hline $\mathrm{K}_{2} \mathrm{O}$ & 0.05 & 9.97 & 0.43 & 0.01 & 0.01 & 0.08 & 8.64 & 10.73 \\
\hline $\mathrm{SO}_{3}$ & 0.14 & 0.13 & 0.14 & 0.02 & 0.00 & 0.00 & 0.00 & 0.10 \\
\hline $\mathrm{NiO}$ & 0.06 & 0.00 & 0.09 & 0.14 & 0.00 & 0.00 & 0.00 & 0.04 \\
\hline Sum & 101.92 & 96.05 & 87.16 & 91.93 & 80.18 & 87.98 & 94.87 & 93.36 \\
\hline $\mathrm{Si}$ & 0.99 & 5.55 & 7.13 & 5.98 & 5.89 & 6.24 & 6.46 & 6.58 \\
\hline $\mathrm{Ti}$ & 0.00 & 0.10 & 0.02 & 0.01 & 0.00 & 0.03 & 0.01 & 0.01 \\
\hline $\mathrm{Al}$ & 0.00 & 2.40 & 3.21 & 4.37 & 4.60 & 4.49 & 4.64 & 4.81 \\
\hline $\mathrm{Fe}^{2+}$ & 0.62 & 2.97 & 3.33 & 3.90 & 4.16 & 3.89 & 0.51 & 0.37 \\
\hline Mn & 0.01 & 0.02 & 0.03 & 0.09 & 0.10 & 0.04 & 0.00 & 0.00 \\
\hline Mg & 1.36 & 3.07 & 5.34 & 5.27 & 4.88 & 4.71 & 0.57 & 0.27 \\
\hline $\mathrm{Ca}$ & 0.01 & 0.01 & 0.05 & 0.04 & 0.06 & 0.09 & 0.30 & 0.00 \\
\hline $\mathrm{Na}$ & 0.00 & 0.00 & 0.00 & 0.21 & 0.24 & 0.00 & 0.00 & 0.00 \\
\hline K & 0.00 & 1.98 & 0.11 & 0.00 & 0.00 & 0.02 & 1.49 & 1.87 \\
\hline S & 0.01 & 0.03 & 0.04 & 0.01 & 0.00 & 0.00 & 0.00 & 0.02 \\
\hline $\mathrm{Ni}$ & 0.00 & 0.00 & 0.01 & 0.02 & 0.00 & 0.00 & 0.00 & 0.00 \\
\hline
\end{tabular}




\begin{tabular}{|c|c|c|c|c|c|c|c|c|}
\hline Sample label & $\begin{array}{l}\text { AP_08_32 } \\
\text { next pl }\end{array}$ & $\begin{array}{l}\text { AP_08_34 } \\
\text { in pl }\end{array}$ & $\begin{array}{l}\text { AP_08_36 } \\
\text { in pl }\end{array}$ & $\begin{array}{l}\text { AP_08_38 } \\
\text { in pl }\end{array}$ & $\begin{array}{l}\text { AP_08_44 } \\
\text { groundmass }\end{array}$ & $\begin{array}{l}\text { AP_08_53 } \\
\text { next amp }\end{array}$ & $\begin{array}{l}\text { AP_08_79 } \\
\text { next cpx }\end{array}$ & $\begin{array}{l}\text { AP_08_80 } \\
\text { next cpx }\end{array}$ \\
\hline $\mathrm{Na}_{2} \mathrm{O}$ & 0.21 & 1.96 & 3.01 & 0.12 & 0.60 & 2.59 & 2.11 & 0.76 \\
\hline $\mathrm{MgO}$ & 4.86 & 0.07 & 0.16 & 6.53 & 0.17 & 0.09 & 0.12 & 0.11 \\
\hline $\mathrm{Al}_{2} \mathrm{O}_{3}$ & 5.56 & 11.64 & 12.12 & 6.00 & 8.19 & 12.87 & 11.25 & 10.16 \\
\hline $\mathrm{SiO}_{2}$ & 60.82 & 72.25 & 74.56 & 68.21 & 58.60 & 73.65 & 72.21 & 67.78 \\
\hline $\mathrm{SO}_{3}$ & 0.01 & 0.11 & 0.00 & 0.08 & 0.08 & 0.11 & 0.00 & 0.12 \\
\hline $\mathrm{K}_{2} \mathrm{O}$ & 0.37 & 5.24 & 5.90 & 0.43 & 2.38 & 4.69 & 5.14 & 1.83 \\
\hline $\mathrm{CaO}$ & 2.36 & 0.43 & 0.34 & 1.92 & 3.04 & 0.54 & 0.40 & 3.10 \\
\hline $\mathrm{TiO}_{2}$ & 0.19 & 0.68 & 0.59 & 0.13 & 0.20 & 0.76 & 0.52 & 0.49 \\
\hline $\mathrm{Cr}_{2} \mathrm{O}_{3}$ & 0.08 & 0.00 & 0.00 & 0.12 & 0.05 & 0.06 & 0.05 & 0.07 \\
\hline $\mathrm{MnO}$ & 0.07 & 0.10 & 0.07 & 0.00 & 0.08 & 0.08 & 0.05 & 0.03 \\
\hline $\mathrm{FeO}$ & 3.93 & 1.90 & 1.61 & 4.52 & 0.29 & 1.41 & 1.66 & 0.86 \\
\hline $\mathrm{NiO}$ & 0.14 & 0.00 & 0.06 & 0.00 & 0.09 & 0.19 & 0.00 & 0.17 \\
\hline Sum & 78.59 & 94.40 & 98.42 & 88.06 & 73.79 & 97.06 & 93.52 & 85.50 \\
\hline
\end{tabular}




\begin{tabular}{|c|c|c|c|c|c|c|c|c|c|c|c|c|}
\hline Weight $\%$ & $\mathrm{SiO}_{2}$ & $\mathrm{Al}_{2} \mathrm{O}_{3}$ & $\mathrm{Fe}_{2} \mathrm{O}_{3}$ & $\mathrm{MnO}$ & $\mathrm{MgO}$ & $\mathrm{CaO}$ & $\mathrm{Na}_{2} \mathrm{O}$ & $\mathrm{K}_{2} \mathrm{O}$ & $\mathrm{TiO}_{2}$ & $\mathrm{P}_{2} \mathrm{O}_{5}$ & LOI & Total \\
\hline AP_01 & 40.78 & 14.57 & 11.49 & 0.168 & 7.7 & 10.29 & 2.35 & 1.82 & 2.099 & 0.38 & 8.81 & 100.4 \\
\hline AP_08 & 41.12 & 14.11 & 15.12 & 0.167 & 5.08 & 7.76 & 2.17 & 1.22 & 2.982 & 0.55 & 9.34 & 99.61 \\
\hline AP_16 & 68.14 & 13.4 & 5.39 & 0.132 & 0.17 & 0.38 & 4.17 & 4.68 & 0.344 & 0.16 & 2.4 & 99.36 \\
\hline AP_17 & 71.58 & 12.17 & 4.18 & 0.073 & 0.24 & 0.62 & 4.1 & 4.44 & 0.249 & 0.02 & 1.54 & 99.21 \\
\hline AP_18 & 57.84 & 16.23 & 8.01 & 0.166 & 3.85 & 5.27 & 3.46 & 1.88 & 0.915 & 0.2 & 2.91 & 100.7 \\
\hline AP_19 & 51.65 & 17.09 & 10.41 & 0.146 & 5.51 & 5.51 & 2.21 & 1.42 & 1.018 & 0.35 & 4.95 & 100.3 \\
\hline AP-20 & 54.08 & 16.7 & 8.6 & 0.164 & 3.22 & 3.48 & 6.19 & 1.03 & 0.989 & 0.24 & 4.18 & 98.88 \\
\hline $\mathrm{ppm}$ & Sc & $\mathrm{Be}$ & V & $\mathrm{Cr}$ & Co & $\mathrm{Ni}$ & $\mathrm{Cu}$ & $\mathrm{Zn}$ & $\mathrm{Ga}$ & $\mathrm{Ge}$ & As & $\mathrm{Rb}$ \\
\hline AP_01 & 26 & 2 & 242 & 180 & 45 & 110 & 70 & 70 & 15 & 1.4 & $<5$ & 50 \\
\hline AP_08 & 21 & 2 & 211 & 30 & 44 & 50 & 30 & 110 & 18 & 1.3 & $<5$ & 38 \\
\hline$A P \_16$ & 1 & 6 & 9 & $<20$ & $<1$ & $<20$ & $<10$ & 150 & 28 & 1.2 & $<5$ & 93 \\
\hline AP_17 & 2 & 7 & 11 & 40 & 2 & $<20$ & 10 & 170 & 31 & 2 & $<5$ & 112 \\
\hline AP_18 & 21 & 1 & 166 & 30 & 22 & $<20$ & 10 & 140 & 15 & 1.3 & 20 & 47 \\
\hline AP_19 & 28 & $<1$ & 229 & 60 & 31 & 30 & 50 & 90 & 16 & 1.1 & 23 & 29 \\
\hline AP-20 & 12 & 1 & 152 & $<20$ & 21 & 20 & $<10$ & 150 & 16 & 2.6 & 5 & 24 \\
\hline $\mathrm{ppm}$ & $\mathrm{Sr}$ & $Y$ & $\mathrm{Zr}$ & $\mathrm{Nb}$ & Mo & $\mathrm{Ag}$ & In & Sn & $\mathrm{Sb}$ & Cs & $\mathrm{Ba}$ & a \\
\hline AP_01 & 466 & 23.5 & 169 & 38.8 & $<2$ & $<0.5$ & $<0.1$ & 1 & $<0.2$ & 7.3 & 330 & 28.8 \\
\hline AP_08 & 188 & 31.4 & 216 & 22.2 & $<2$ & $<0.5$ & $<0.1$ & 1 & 0.3 & 4 & 169 & 19.2 \\
\hline AP_16 & 241 & 99.5 & 806 & 59 & $<2$ & 1.5 & 0.2 & 7 & $<0.2$ & 0.2 & 117 & 45.9 \\
\hline AP_17 & 26 & 134 & 1118 & 71 & 2 & 6.4 & 0.2 & 8 & $<0.2$ & 0.2 & 63 & 72.4 \\
\hline AP_18 & 435 & 24.9 & 154 & 4.2 & $<2$ & $<0.5$ & $<0.1$ & 1 & 3.4 & 1 & 633 & 12 \\
\hline AP_19 & 462 & 17.5 & 75 & 2 & $<2$ & $<0.5$ & $<0.1$ & $<1$ & 1.9 & 1.5 & 781 & 9.33 \\
\hline AP-20 & 369 & 17.2 & 105 & 2.1 & 2 & $<0.5$ & 0.1 & $<1$ & 3.7 & 0.7 & 213 & 10 \\
\hline $\mathrm{ppm}$ & $\mathrm{Ce}$ & $\mathrm{Pr}$ & $\mathrm{Nd}$ & $\mathrm{Sm}$ & $\mathrm{Eu}$ & $\mathrm{Gd}$ & $\mathrm{Tb}$ & Dy & Ho & $\mathrm{Er}$ & $\mathrm{Tm}$ & $\mathrm{Yb}$ \\
\hline AP_01 & 59.5 & 6.98 & 28.2 & 6.02 & 1.92 & 5.35 & 0.8 & 4.6 & 0.83 & 2.26 & 0.308 & 2.06 \\
\hline AP_08 & 46.6 & 6.21 & 28.4 & 6.78 & 2.35 & 6.98 & 1.05 & 5.87 & 1.11 & 3.19 & 0.434 & 2.73 \\
\hline AP_16 & 127 & 13.8 & 54.7 & 14 & 1.86 & 14.6 & 2.63 & 16.6 & 3.38 & 10.1 & 1.55 & 10.5 \\
\hline AP_17 & 162 & 18.8 & 75.3 & 17.9 & 1.56 & 18.7 & 3.5 & 22.8 & 4.6 & 14.1 & 2.14 & 14.4 \\
\hline AP_18 & 29.2 & 3.89 & 17.4 & 4.34 & 1.16 & 4.36 & 0.72 & 4.33 & 0.85 & 2.47 & 0.358 & 2.44 \\
\hline AP_19 & 22.7 & 3.32 & 15.5 & 3.8 & 1.26 & 3.69 & 0.55 & 3.11 & 0.62 & 1.71 & 0.258 & 1.67 \\
\hline AP-20 & 24.7 & 3.44 & 16.3 & 4.21 & 1.3 & 3.78 & 0.57 & 3.17 & 0.61 & 1.61 & 0.23 & 1.47 \\
\hline
\end{tabular}

\begin{tabular}{lrrrrrrrrr} 
ppm & Lu & Hf & Ta & W & Tl & Pb & Bi & Th & U \\
\hline AP_01 & 0.311 & 3.7 & 2.68 & $<0.5$ & 0.09 & $<5$ & $<0.1$ & 2.99 & 0.89 \\
AP_08 & 0.438 & 4.4 & 1.52 & $<0.5$ & 0.11 & $<5$ & $<0.1$ & 1.48 & 0.64 \\
AP_16 & 1.62 & 15.8 & 4.28 & $<0.5$ & 0.13 & 20 & $<0.1$ & 8.54 & 2.01 \\
AP_17 & 2.2 & 25.3 & 6.5 & $<0.5$ & 0.1 & 20 & $<0.1$ & 13.2 & 3.8 \\
AP_18 & 0.38 & 3.8 & 0.27 & $<0.5$ & 0.26 & $<5$ & $<0.1$ & 1.71 & 1.02 \\
AP_19 & 0.244 & 1.9 & 0.07 & $<0.5$ & $<0.05$ & $<5$ & $<0.1$ & 0.14 & 0.24 \\
AP-20 & 0.235 & 2.4 & 0.06 & $<0.5$ & 0.16 & 7 & 0.3 & 0.58 & 0.43 \\
\hline
\end{tabular}

$\mathrm{Fe}_{2} \mathrm{O}_{3}=$

total iron 


\begin{tabular}{|c|c|c|c|c|c|c|}
\hline Sample \# & Dyke type & Lithology & Coordinates & Host rocks & Inferences \& Remarks & Possible tectonic setting \\
\hline AP-01 & Basaltic & Basanite & $\begin{array}{l}\text { Latitude: } \\
27.504511^{\circ} \mathrm{N} \\
\text { Longitude: } \\
36.121809^{\circ} \mathrm{E}\end{array}$ & $\begin{array}{c}\text { alkali granite of the } \\
\text { Massah complex } 629 \pm 12 \\
\text { Ma (Grainger and Hanif } \\
\text { 1989) (Midyan terrane). }\end{array}$ & $\begin{array}{l}\text { Subvolcanic (based on fine- } \\
\text { grained crystallinity) dyke } \\
\text { emplaced in } \\
\text { divergent tectonic } \\
\text { environment }\end{array}$ & Red Sea rifting \\
\hline AP-03* & Granitoid & Granite & $\begin{array}{l}\text { Latitude: } \\
27.535205^{\circ} \mathrm{N} \\
\text { Longitude: } \\
36.457635^{\circ} \mathrm{E}\end{array}$ & $\begin{array}{l}\text { Qaraqir alkali granite } \\
\text { (Midyan terrane) }\end{array}$ & $\begin{array}{c}\text { Intrusive (as suggested by } \\
\text { coarse-grained crystallinity) } \\
\text { dyke probably emplaced due } \\
\text { to suturing event }\end{array}$ & Arabian shield accretion \\
\hline AP-05* & Granitoid & Monzogranite & $\begin{array}{l}\text { Latitude: } \\
27.534905^{\circ} \mathrm{N} \\
\text { Longitude: } \\
36.458497^{\circ} \mathrm{E}\end{array}$ & $\begin{array}{l}\text { Qaraqir alkali granite } \\
\text { (Midyan terrane) }\end{array}$ & $\begin{array}{l}\text { Intrusive (as suggested by } \\
\text { coarse-grained crystallinity) } \\
\text { dyke probably emplaced due } \\
\text { to suturing event }\end{array}$ & Arabian shield accretion \\
\hline AP-08 & Basaltic & Basalt & $\begin{array}{l}\text { Latitude: } \\
26.488274^{\circ} \mathrm{N} \\
\text { Longitude: } \\
36.389255^{\circ} \mathrm{E}\end{array}$ & $\begin{array}{l}\text { Liban monzogranite } 621 \pm 7 \\
\text { Ma or } 638 \pm 10 \text { Ma (Hedge, } \\
\text { in Al-Husseini 2015) } \\
\text { (Midyan terrane) }\end{array}$ & $\begin{array}{l}\text { Subvolcanic (based on fine- } \\
\text { grained crystallinity) dyke } \\
\text { emplaced in } \\
\text { divergent tectonic } \\
\text { environment }\end{array}$ & Red Sea rifting \\
\hline AP-14* & Granitoid & Granodiorite & $\begin{array}{l}\text { Latitude: } \\
25.188390^{\circ} \mathrm{N} \\
\text { Longitude: } \\
37.416037^{\circ} \mathrm{E}\end{array}$ & $\begin{array}{l}\text { Neoproterozoic gabbroic } \\
\text { rocks (Midyan terrane) }\end{array}$ & $\begin{array}{l}\text { Intrusive (as suggested by } \\
\text { coarse-grained crystallinity) } \\
\text { dyke probably emplaced due } \\
\text { to suturing event }\end{array}$ & Arabian shield accretion \\
\hline AP-16 & Rhyolite & Rhyolite & $\begin{array}{l}\text { Latitude: } \\
20.914031^{\circ} \mathrm{N} \\
\text { Longitude: } \\
39.901878^{\circ} \mathrm{E}\end{array}$ & $\begin{array}{l}\text { meta-basalts of the Baish } \\
\text { group protoliths older than } \\
804 \mathrm{Ma} \text { (Asir composite } \\
\text { terrane) }\end{array}$ & $\begin{array}{l}\text { Subvolcanic (based on fine- } \\
\text { grained crystallinity) dyke } \\
\text { emplaced during continental } \\
\text { rifting }\end{array}$ & Red Sea rifting \\
\hline AP-17 & Rhyolite & Rhyolite & $\begin{array}{l}\text { Latitude: } \\
20.896851^{\circ} \mathrm{N} \\
\text { Longitude: } \\
39.891866^{\circ} \mathrm{E}\end{array}$ & $\begin{array}{c}\text { meta-basalts of the Baish } \\
\text { group protoliths older than } \\
804 \mathrm{Ma} \text { (Asir composite } \\
\text { terrane) }\end{array}$ & $\begin{array}{l}\text { Subvolcanic (based on fine- } \\
\text { grained crystallinity) dyke } \\
\text { emplaced during continental } \\
\text { rifting }\end{array}$ & Red Sea rifting \\
\hline AP-18 & Andesitic & Andesite & $\begin{array}{l}\text { Latitude: } \\
\text { 24.6262148 } \mathrm{N} \\
\text { Longitude: } \\
38.0937260^{\circ} \mathrm{E}\end{array}$ & $\begin{array}{l}\text { Neoproterozoic granitoid } \\
\text { complex (Hijaz terrane) }\end{array}$ & $\begin{array}{l}\text { Subvolcanic (based on fine- } \\
\text { grained crystallinity) of } \\
\text { convergent tectonic } \\
\text { environment }\end{array}$ & Arabian shield accretion \\
\hline AP-19 & Andesitic & $\begin{array}{l}\text { Basaltic } \\
\text { andesite }\end{array}$ & $\begin{array}{l}\text { Latitude: } \\
24.6249047^{\circ} \mathrm{N} \\
\text { Longitude: } \\
38.0948120^{\circ} \mathrm{E}\end{array}$ & $\begin{array}{l}\text { Neoproterozoic granitoid } \\
\text { complex (Hijaz terrane) }\end{array}$ & $\begin{array}{l}\text { Subvolcanic (based on fine- } \\
\text { grained crystallinity) of } \\
\text { convergent tectonic } \\
\text { environment }\end{array}$ & Arabian shield accretion \\
\hline AP-20 & Andesitic & Trachyandesite & $\begin{array}{l}\text { Latitude: } \\
24.6371164^{\circ} \mathrm{N} \\
\text { Longitude: } \\
38.0697803^{\circ} \mathrm{E}\end{array}$ & $\begin{array}{l}\text { Neoproterozoic granitoid } \\
\text { complex (Hijaz terrane) }\end{array}$ & $\begin{array}{l}\text { Subvolcanic (based on fine- } \\
\text { grained crystallinity) of } \\
\text { convergent tectonic } \\
\text { environment }\end{array}$ & Arabian shield accretion \\
\hline
\end{tabular}

